Original article

\title{
Effects of quercetin, naringenin and EGCG on 5HT and histamine induced contraction in pulmonary artery and its modulation by hypoxia
}

\author{
Santwana Palai, Kautuk K. Sardar, Prakash C. Behera* and Subash C. Parija \\ Department of Veterinary Pharmacology and Toxicology, College of Veterinary Science and Animal Husbandry, \\ Orissa University of Agriculture and Technology, Bhubaneswar-751003, Odisha, India \\ *Department of Veterinary Biochemistry, College of Veterinary Science and Animal Husbandry, \\ Orissa University of Agriculture and Technology, Bhubaneswar-751003, Odisha, India
}

Received October 10, 2017: Revised November 25, 2017: Accepted November 30, 2017: Published online December 30, 2017

\begin{abstract}
The importance and role of phytochemicals in promoting good health by its antioxidant effect is well documented. The aim of this work was to investigate the effect of three defined polyphenols such as quercetin, naringenin and EGCG on vasotonic response induced by activation of serotonin and histamine receptor in pulmonary artery of $C$. hircus (PA of $C h$ ). The arterial rings prepared from secondary branch of pulmonary artery of $C$. hircus was mounted in automatic organ bath. Isometric contraction induced by $5 \mathrm{HT}$ and histamine $(1 \mathrm{nM}-100 \mu \mathrm{M})$ under normoxic or hypoxic conditions was recorded in absence or presence of quercetin, naringenin and EGCG. The maximum contractile response $\left(\mathrm{E}_{\max }\right)$ induced by $5 \mathrm{HT}$ and histamine in normoxic rings was almost reduced by more than $50 \%$ in hypoxic one. The $\mathrm{E}_{\max }$ obtained from $5 \mathrm{HT}$ induced contractile response curve was greater than histamine in both normoxic and hypoxic rings. The $\mathrm{E}_{\max }$ obtained from 5HT-induced contractile response curve in presence of quercetin, naringenin, EGCG was reduced by $44 \%, 63 \%, 38 \%$, in normoxic rings and by $85 \%, 93 \%, 89 \%$ in hypoxic rings, respectively Similarly, the $\mathrm{E}_{\max }$ obtained from histamine-induced contractile response curve in presence of quercetin, naringenin, EGCG was reduced by $36 \%, 51 \%, 60 \%$ in normoxic rings and by $89 \%, 83 \%$, $84 \%$, respectively in hypoxic rings. In conclusion, (i) the PA of $\mathrm{Ch}$ is more sensitive to $5 \mathrm{HT}$ than histamine while eliciting contractile response, (ii) the hypoxic state attenuated the 5HT and histamine receptor activated contractile response, (iii) the relative inhibitory effect of quercetin, naringenin and EGCG on 5HT and histamine-induced contraction is in the order of naringenin> quercetin> EGCG and EGCG> naringenic> quercetin, respectively, in normoxic state, (iv) in hypoxic PA rings the inhibitory effect of quercetin, naringenin and EGCG on 5HT and histamineinduced contraction were almost identical (83-93\%). In translating the observation, it is recommended that quercetin, naringenin and EGCG could be useful in decreasing vascular resistance of pulmonary artery and thereby controlling the pulmonary hypertension.
\end{abstract}

Key words: Quercetin, naringenin, EGCG, pulmonary artery contraction, hypoxia

\section{Introduction}

Pulmonary arterial hypertension (PAH) is a disease of increase in pulmonary vascular resistance and remodelling involving dysfunction of the endothelin, prostacyclin pathway and nitric oxide pathways, leading to right ventricular failure and premature death (Boucherat et al., 2015). The available therapies (phosphodiesterase type 5 inhibitors, endothelin-1 receptor antagonists or prostacyclin mimetics) relieve symptoms and slow the progress of the disease but has no certain cure (Sitbon et al., 2014). Thus, there is a necessity for novel effective therapeutic strategies for $\mathrm{PAH}$.

\footnotetext{
Author for correspondence: Dr. Subash C. Parija

Professor, Department of Veterinary Pharmacology and Toxicology, College of Veterinary Science and Animal Husbandry, Orissa University of Agriculture and Technology, Bhubaneswar-751003, Odisha, India E-mail: profscparijaouat4691@gmail.com Tel.: +91-9437356387
}

Copyright @ 2017 Ukaaz Publications. All rights reserved.

Email: ukaaz@yahoo.com; Website: www.ukaazpublications.com
Quercetin [2-(3,4-Dihydroxyphenyl)-3,5,7-trihydroxy-4Hchromen-4-one], a flavonoid present in onions, apples, peppers, tomatoes, cruciferous vegetables including broccoli, cabbage and sprouts (Hertog et al.,1993) is an antioxidant (Morel et al., 1993), antimutagenic (Harwood et al., 2007), anti-inflammatory (Rogelio et al., 2007), leishmanicidal (Marín et al., 2009), antihypertensive (Duarte et al., 2001; Yamamoto and Oue, 2006), iron chelator (Ferrali et al., 1997) and vasorelaxant (Chen and Pace-Asciak, 1996, Chen et al., 2004). Naringenin [(2S)-5,7-Dihydroxy-2-(4hydroxyphenyl)-2,3-dihydro-4H-chromen-4-one], a citrus flavonoid found in grapefruit, bitter orange and other fruits (Liu et al., 2016) has anti-inflammatory (Tsai et al., 2012), antimutagenic (Shi et al., 2009), antioxidant (Mershiba et al., 2013), anticancerous (Abaza et al., 2015), antiatherogenic (Lee et al., 2003), vasorelaxant (Ajay et al., 2003) with vasoactivity (Saponara et al., 2006) and GI regulator (Yang et al., 2014; Sanders et al., 2014) properties. Epigallocatechin-3-gallate (EGCG) [(2R,3R)-5,7-Dihydroxy-2(3,4,5-trihydroxyphenyl)-3,4-dihydro-2H-chromen-3-yl 3,4,5trihydroxybenzoate], a catechin from green tea (Camellia sinensis) leaves is a poteintial source of antioxidant (Guo et al., 2005; Weinreb 
et al., 2004), radical scavenger (Weinreb et al., 2004), metal chelator, anti-carcinogen (Lambert and Elias, 2010), anti-apoptotic (Nie et al., 2002) and anti-inflammatory (Singh et al., 2010).

Table 1: $5 \mathrm{HT}(1 \mathrm{nM}-100 \mu \mathrm{M})$ and histamine $(1 \mathrm{nM}-100 \mu \mathrm{M})$ induced concentration related contractile response in absence $\left(\mathrm{E}_{\mathrm{max}}\right)$ or in presence $\left(\mathrm{E}_{\mathrm{Bmax}}\right)$ of quercetin $(10 \mu \mathrm{M})$, naringenin $(10$ $\mu \mathrm{M}) \& \mathrm{EGCG}(10 \mu \mathrm{M})$ in normoxic and hypoxic pulmonary arterial rings of $C$. hircus

\begin{tabular}{|c|c|c|c|c|}
\hline & \multicolumn{2}{|c|}{ Normoxic $(\mathbf{N})$} & \multicolumn{2}{|c|}{ Hypoxic(H) } \\
\hline $\begin{array}{l}\text { treatment } \\
\text { groups }\end{array}$ & $\mathbf{E C}_{50}$ & $\mathbf{E}_{\max }, \mathbf{E}_{\mathrm{Bmax}}(\mathbf{g m})$ & $\mathbf{E C}_{50}$ & $\mathbf{E}_{\max /} \mathbf{E}_{\text {Bmax }}(\mathbf{g m})$ \\
\hline 5HT & $5.77 \pm 0.01$ & $1.34 \pm 0.16$ & $4.71 \pm 0.01^{c}$ & $0.50 \pm 0.004^{c}$ \\
\hline 5HT +Quer & $5.64 \pm 0.02^{a}$ & $0.76 \pm 0.06^{a}$ & $3.46 \pm 0.50$ ad & $0.20 \pm 0.03$ ac \\
\hline 5HT + Nari & $5.45 \pm 0.02^{a}$ & $0.50 \pm 0.03$ a & $4.81 \pm 0.003$ ac & $0.10 \pm 0.02$ ac \\
\hline 5HT+ EGCG & $4.66 \pm 0.001^{a}$ & $0.83 \pm 0.04^{a}$ & $5.11 \pm 0.002^{a c}$ & $0.41 \pm 0.044^{a c}$ \\
\hline Histamine & $5.01 \pm 0.01$ & $1.22 \pm 0.06$ & $4.85 \pm 0.01^{\mathrm{c}}$ & $0.45 \pm 0.05^{c}$ \\
\hline Hist + Quer & $5.40 \pm 0.004^{a}$ & $0.78 \pm 0.02^{a}$ & $4.62 \pm 0.02 \mathrm{ac}$ & $0.14 \pm 0.01$ ac \\
\hline Hist + Nari & $5.29 \pm 0.03^{a}$ & $0.60 \pm 0.05^{a}$ & $5.13 \pm 0.06$ ad & $0.21 \pm 0.004^{a c}$ \\
\hline Hist+ EGCG & $5.35 \pm 0.04^{a}$ & $0.49 \pm 0.04^{a}$ & $4.99 \pm 0.01$ ac & $0.20 \pm 0.01$ ad \\
\hline
\end{tabular}

$a(p<0.001)$ and $b(p<0.05)$ represent level of significance between the rows within each column. Data of each row (hypoxic) is compared with the data of normoxic (control) within corresponding column. $c(p<0.001)$ and $d(p<0.05)$ represent level of significance between the sub-columns ( $\mathrm{N}$ and $\mathrm{H}$ ) within each row. Data of each ' $\mathrm{H}$ ' column in a particular row is compared with the corresponding data of ' $N$ ' column.

The effect of quercetin is partly endothelium-dependent (Ajay et al., 2003; Khoo et al., 2010) involving nitric oxide in rat isolated thoracic aorta (Chen and Pace-Asciak, 1996 ; Chan et al., 2000 ; Ajay et al., 2003) and endothelium-independent in isolated rat vascular smooth muscle (Duarte et al.,1993); isolated rat thoracic and abdominal aorta, isolated iliac arteries and mesenteric resistance vascular bed (Perez-Vizcaino et al.,2002) and a combination of these actions in rat aorta ring preparations and single tail artery myocytes (Fusi et al., 2003).

Naringenin has a relaxant effect on vascular smooth muscle of rat thoracic aorta (Ajay et al., 2003); rat and bovine aorta (Orallo et al., 2005), rat thoracic aortic rings (Saponara et al., 2006); mouse isolated stomach (Amira et al., 2008); rat colonic smooth muscle (Yang et al., 2014); interstitial cells of Cajal from murine small intestine (Kim \& Kim, 2017) and protects diabetic rats (Fallahi et al., 2012).

The vasodilating effects of EGCG rely on eNOS and NO production in endothelial cells in isolated aortic rings of endothelial NO knockout mice (Lorenz et al., 2015), rat aorta (Alvarez et al., 2006); improve cardiovascular and metabolic function in spontaneously hypertensive rats (Potenza et al., 2007) ; porcine coronary artery rings (Auger et al., 2010), rat thoracic aorta (Aggio et al., 2013); mesenteric vascular beds from WKY rats (Kim et al., 2007); endothelial cells of bovine (Lorenz et al., 2004). The chemical structure and natural source of quercetin, naringenin and EGCG is given in (Figures 1A, 1B and 1C), respectively.

Considering hypoxia as the major reason of pulmonary arterial hypertension in man and animal, the present study investigates the effect of hypoxia on vasotonic response to 5HT and histamine in pulmonary artery of goat (C. hircus ) (PA of $C h$ ) in absence and presence of quercetin, naringenin and EGCG. The experimental protocol would answer the questions like: (i) how does PA of $C h$ responds to contraction induced by $5 \mathrm{HT}$ and histamine, (ii) whether quercetin, naringenin and EGCG cause any vasodilatory effect in these serotonergic and histaminergic receptor-activated contraction, (iii) whether goat pulmonary artery could be employed as model for study for vasorelaxation under hypoxia and (iv) Lastly, if these polyphenols would be useful in ameliorating the altered vasoreactivity of PA of $C h$ under hypoxia or not.

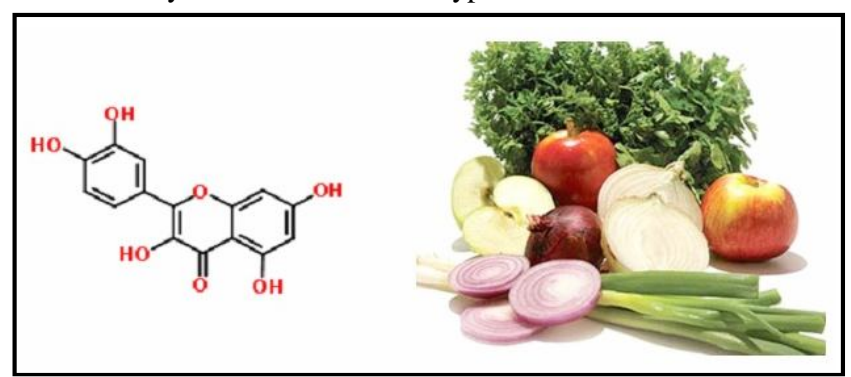

Figure 1A: Chemical structure of quercetin and natural sourcesonions, apples, tomatoes, cruciferous vegetables.

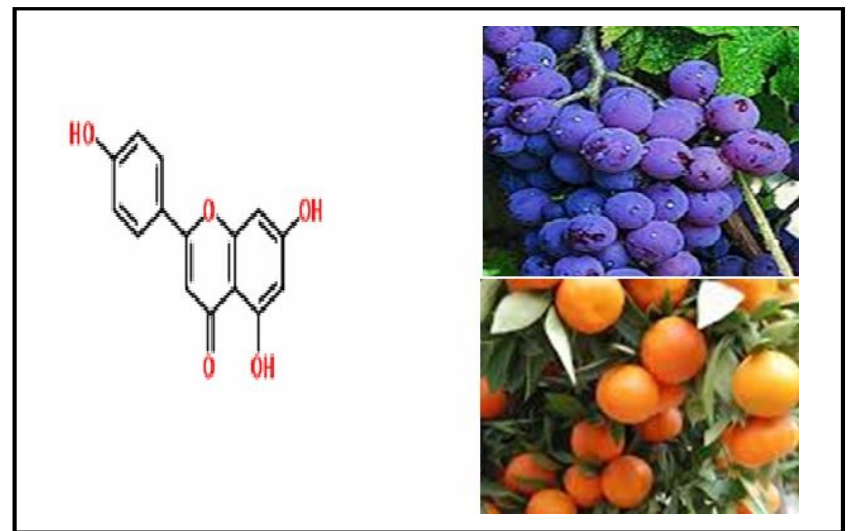

Figure 1B: Chemical structure of naringenin and natural sourcesgrapes, orange

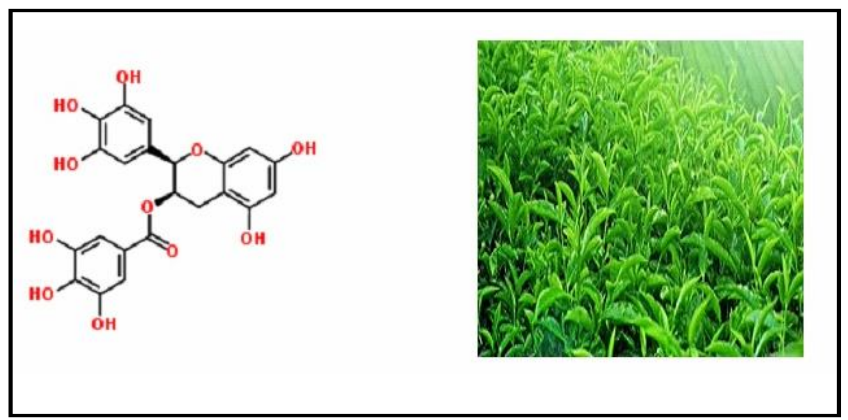

Figure 1C : Chemical structure of ECGC and natural source- green tea.

\section{Materials and Methods}

The whole lungs containing branches of pulmonary artery obtained from freshly slaughtered goat of local abattoir was transferred in ice cold Modified Krebs-Henseleit Solution (MKHS) to the laboratory. The arteries were cleared of connective tissues, fascia then cut into segments of circular rings measuring $1.5-2 \mathrm{~mm}$ in length and employed for isometric contraction studies. Freshly prepared arterial rings were mounted with the isometric force 
transducer (MLT 0201) positioned on a micro-positioner (Panlab S.I., Spain). Then the arterial rings were equilibrated in MKHS under a resting tension of $1.0 \mathrm{~g}$ for a period of $60 \mathrm{~min}$ with washing at 15 min interval with MKHS maintained at $\mathrm{pH}$ of 7.2-7.4. Following the equilibration period, the vasocontractility was elicited by exposing the arterial rings to ligands. The secondary branch of isolated pulmonary artery of $C$. hircus was mounted in a four chambered automatic organ bath and exposed to vasotonic agent like 5HT (10 $\mathrm{nM}-100 \mu \mathrm{M})$ and histamine $(10 \mathrm{nM}-100 \mu \mathrm{M})$ in presence of polyphenols like quercetin $(10 \mu \mathrm{M})$, naringenin $(10 \mu \mathrm{M})$ and EGCG $(10 \mu \mathrm{M})$ under normoxic and hypoxic conditions. Separate sets of experiments were conducted for different treatment and control groups. The isometric contraction was recorded by personal computer with the help of Lab chart 7 pro software (AD Instrument software, Australia). The tissue holder along with arterial ring was placed in vessel containing $20 \mathrm{ml}$ of MKHS ( $\mathrm{pH} 7.2-7.4$ ) maintained at $\left(37.0 \pm 0.5^{\circ} \mathrm{C}\right)$ and bubbled with carbogen $\left(95 \% \mathrm{O}_{2}+5 \% \mathrm{CO}_{2}\right)$ as normoxic condition and with nominal oxygen $\left(1 \% \mathrm{O}_{2}+4 \% \mathrm{CO}_{2}+\right.$ $95 \% \mathrm{~N}_{2}$ ) simulating hypoxic condition for the hypoxia model. The isometric contraction was recorded by PC with the help of Lab chart 7 pro software (AD Instrument software, Australia). All the experiments were carried after approval from IAEC, C.V.Sc and $\mathrm{AH}$ (Regd No.433CPCSEA/CVS/2007)

\subsection{Statistical analysis}

All values are expressed as mean \pm Standard error of mean (SEM) of measurements in ' $n$ ' experiments. The net contraction was expressed as mean $\mathrm{gm}$. The data was compared using unpaired student's ' $t$ ' test using GraphPad Software Quick Calcs. The mean- $\operatorname{logEC}_{50}$ and maximal contraction $\left(\mathrm{E}_{\max }\right)$ was calculated using Graph-Pad Prism 5 software (GraphPad Prism5, GraphPad Software Inc., San Diego, CA, U.S.A). A ' $p$ ' value $<0.05$ and $p<0.001$ was considered statistically significant.

\section{Results}

Effect of quercetin $(10 \mu \mathrm{M})$, naringenin $(10 \mu \mathrm{M})$ and EGCG $(10 \mu \mathrm{M})$ on $5 \mathrm{HT}(1 \mathrm{nM}-100 \mu \mathrm{M})$ concentration related contractile response elicited in normoxic and hypoxic pulmonary arterial rings.

5HT- induced CRC response curve elicited in presence of quercetin $(10 \mu \mathrm{M})$ was shifted to right with significant $(p<0.001)$ decrease in $\mathrm{EC}_{50}$ and $\mathrm{E}_{\mathrm{Bmax}}(5.64 \pm 0.02$ and $0.76 \pm 0.06 \mathrm{~g}, \mathrm{n}=6)$ in normoxic condition as compared non-treated normoxic control $\left(\mathrm{EC}_{50} 5.77 \pm\right.$ $0.01, \mathrm{E}_{\max } 1.34 \pm 0.16 \mathrm{~g}, \mathrm{n}=6$ ). Similarly, in presence of quercetin 5HT-induced CRC response curve was shifted to right with significant $(p<0.05, p<0.001)$ decrease in $\mathrm{EC}_{50}$ and $\mathrm{E}_{\mathrm{Bmax}}(3.46 \pm$ $0.5,0.2 \pm 0.03 \mathrm{~g}, \mathrm{n}=6$ ) in hypoxic rings as compared to that of $\mathrm{EC}_{50}$ and $\mathrm{E}_{\mathrm{Bmax}}$ of treated normoxic group (Figures 2A, B, C).

In presence of naringenin $(10 \mu \mathrm{M})$, 5HT-induced CRC response curve was shifted to right with significant $(p<0.001)$ decrease in $\mathrm{EC}_{50}$ and $\mathrm{E}_{\mathrm{Bmax}}(5.45 \pm 0.020 .5 \pm 0.03 \mathrm{~g}, \mathrm{n}=6)$ in normoxic condition as compared to non-treated normoxic control $\left(\mathrm{EC}_{50} 5.77 \pm 0.01\right.$, $\mathrm{E}_{\max } 1.34 \pm 0.16 \mathrm{~g}, \mathrm{n}=6$ ). Similarly, 5HT-induced CRC response curve elicited in presence of naringenin was shifted to right with significant $(p<0.001)$ decrease in $\mathrm{EC}_{50}$ and $\mathrm{E}_{\mathrm{B} \max }(4.81 \pm 0.003 \mu \mathrm{M}$, $0.10 \pm 0.02 \mathrm{~g}, \mathrm{n}=6$ ) in hypoxic rings in comparison with that of $\mathrm{EC}_{50}$ and $\mathrm{E}_{\mathrm{Bmax}}$ of treated normoxic group (Figures 3A, B, C).

CRC response curve elicited by $5 \mathrm{HT}$ in presence of EGCG $(10 \mu \mathrm{M})$ was shifted to right with significant $(p<0.001)$ decrease in $\mathrm{EC}_{50}$ and $\mathrm{E}_{\mathrm{Bmax}}(4.66 \pm 0.001 \mu \mathrm{M}, 0.83 \pm 0.04 \mathrm{~g}, \mathrm{n}=6)$ in normoxic condition as compared to non-treated normoxic control $\left(\mathrm{EC}_{50} 5.77\right.$ $\pm 0.01, \mathrm{E}_{\max } 1.34 \pm 0.16 \mathrm{~g}, \mathrm{n}=6$ ). Similarly, 5HT induced CRC response curve elicited in presence of EGCG was shifted to right with significant $(p<0.001)$ increase in $\left(\mathrm{EC}_{50} 5.11 \pm 0.002 \mu \mathrm{M}\right)$ and significant $(p<0.001)$ decrease in $\left(\mathrm{E}_{\max } 0.41 \pm 0.04 \mathrm{~g}, \mathrm{n}=6\right)$ in hypoxic rings in comparison with that of $\mathrm{EC}_{50}$ and $\mathrm{E}_{\mathrm{Bmax}}$ of treated normoxic group (Figures, 4 A, B, C).

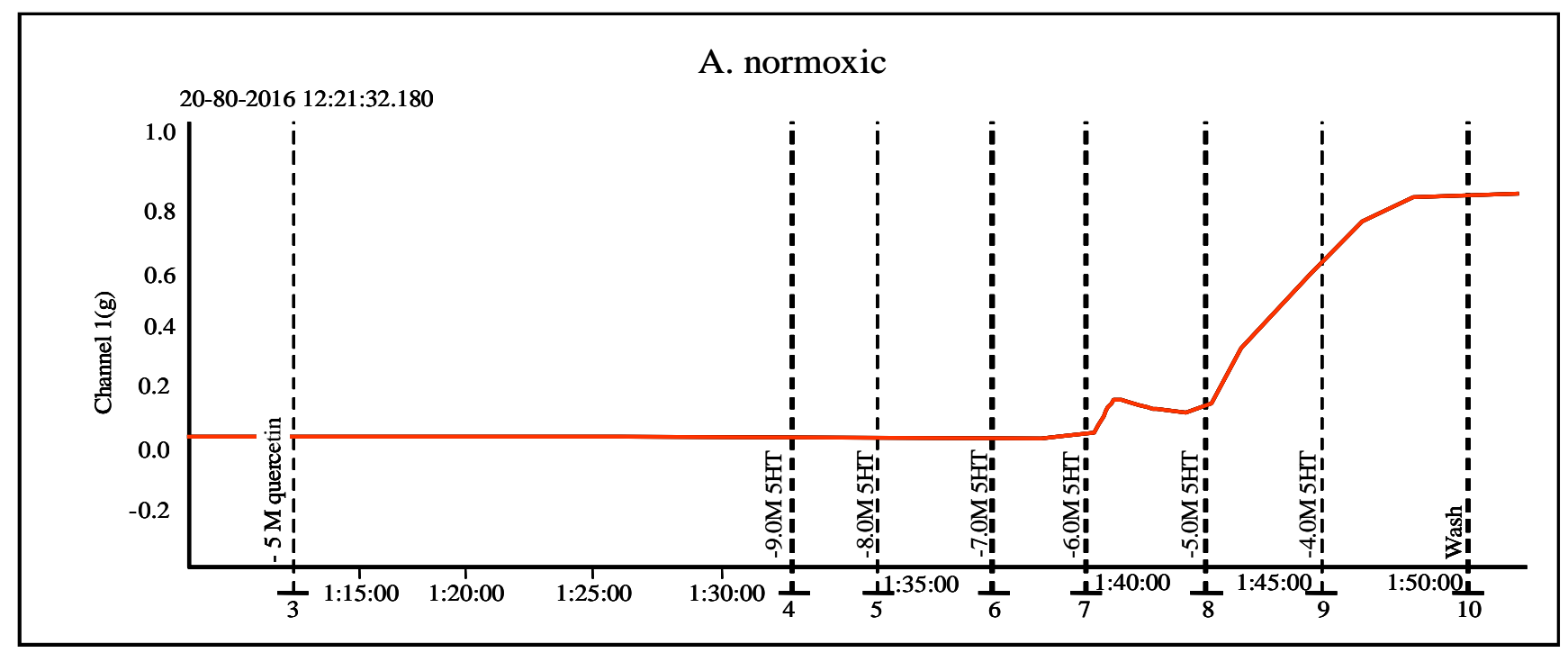




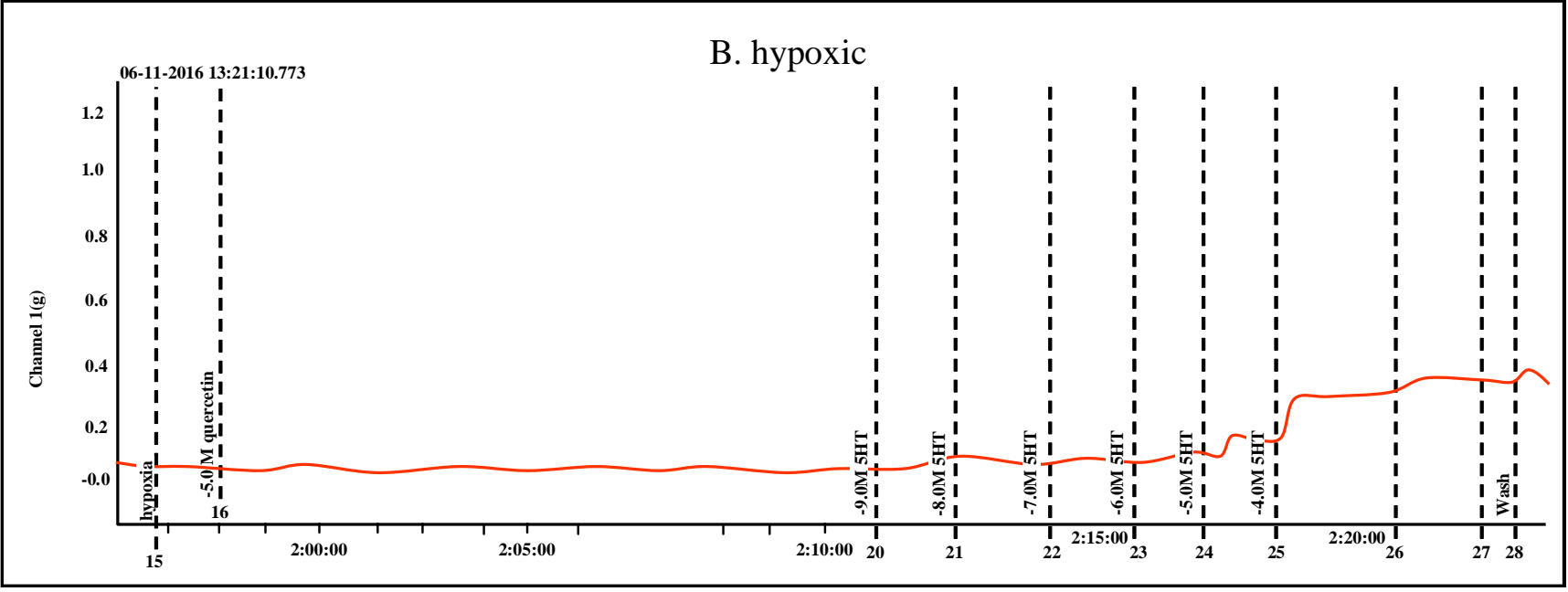

Figure 2: Representative raw trace showing effect of $5 \mathrm{HT}(1 \mathrm{nM}-100 \mu \mathrm{M})$ induced concentration related contractile response in presence of quercetin $(10 \mu \mathrm{M})$ in normoxic and hypoxic rings.

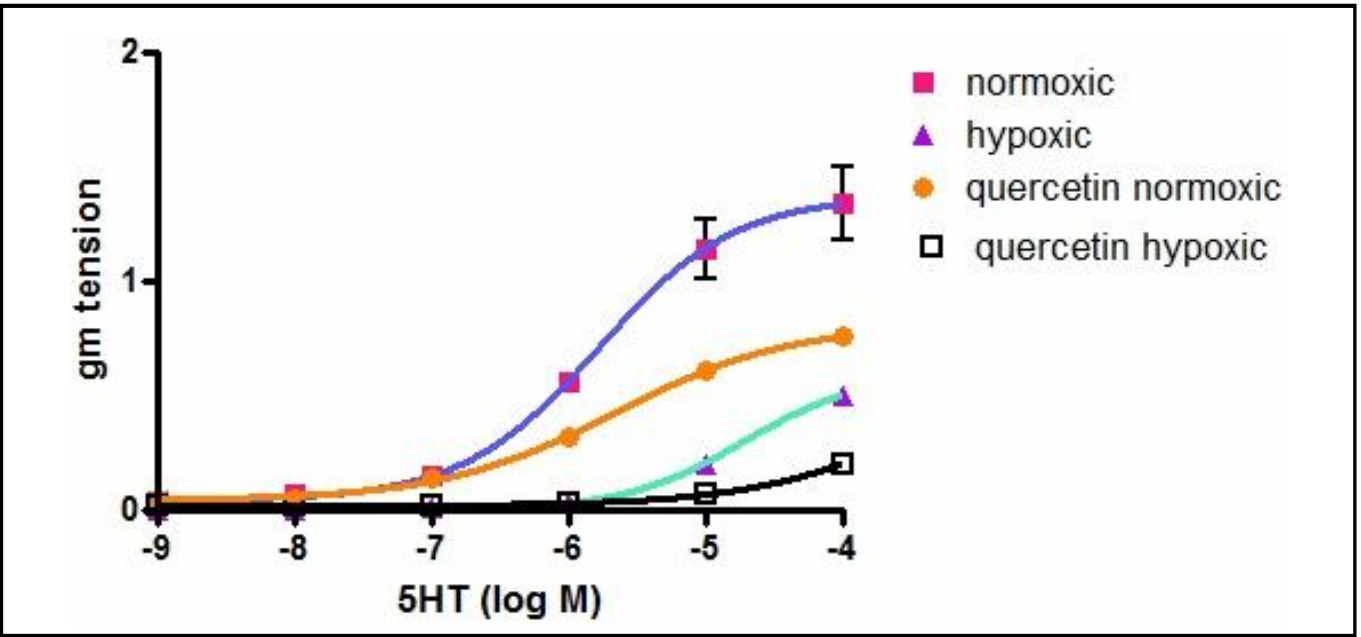

Figure 2C: 5 HT $(1 \mathrm{nM}-100 \mu \mathrm{M})$ induced concentration related contractile response in absence $\left(\mathrm{E}_{\max }\right)$ or in presence $\left(\mathrm{E}_{\mathrm{Bmax}}\right)$ of quercetin in normoxic and hypoxic pulmonary arterial rings of $C$. hircus.

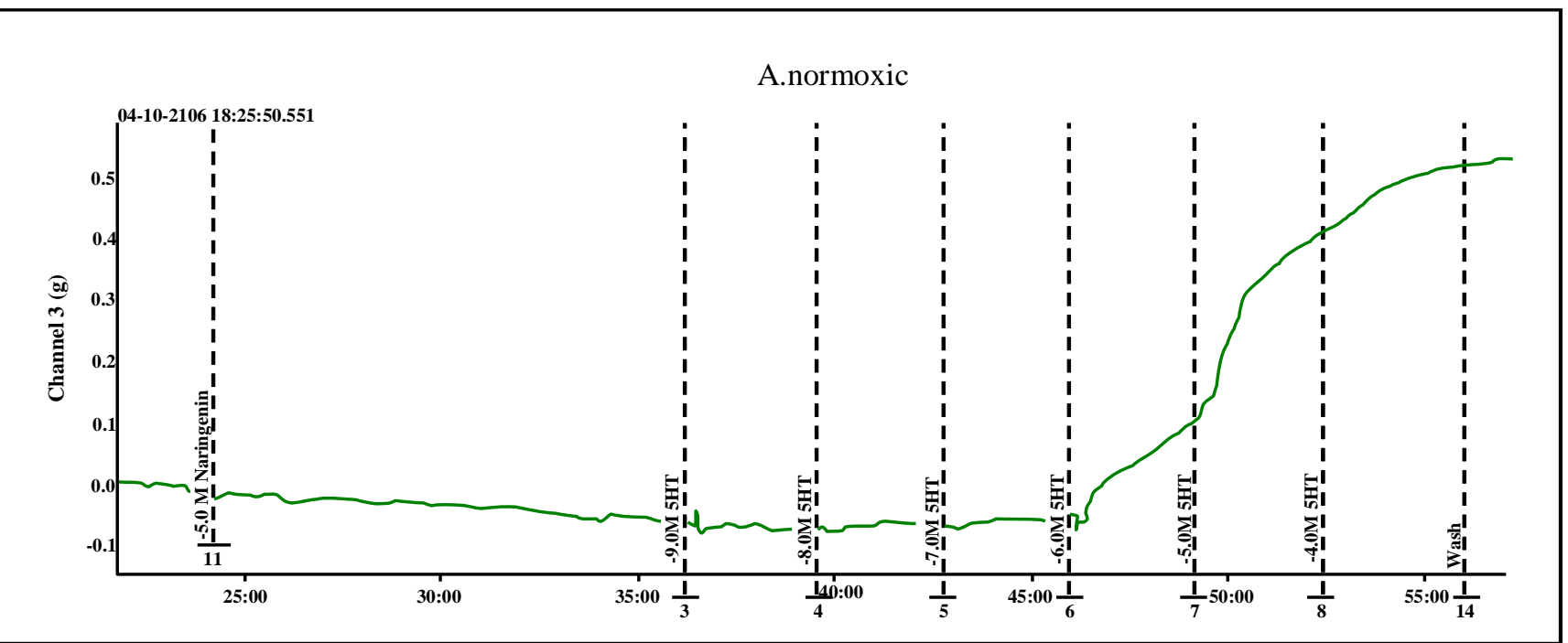




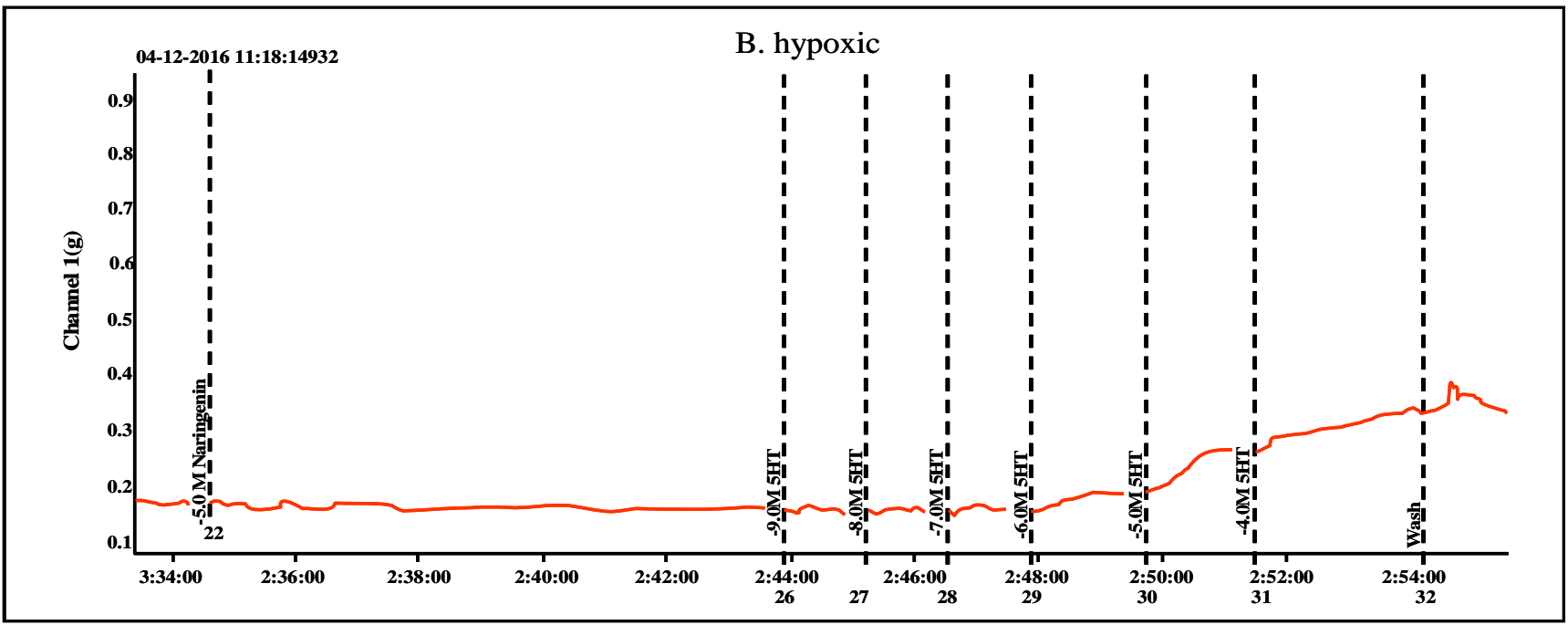

Figure 3: Representative raw trace showing effect of $5 \mathrm{HT}(1 \mathrm{nM}-100 \mu \mathrm{M})$ induced concentration related contractile response in presence of naringenin $(10 \mu \mathrm{M})$ in normoxic and hypoxic rings.

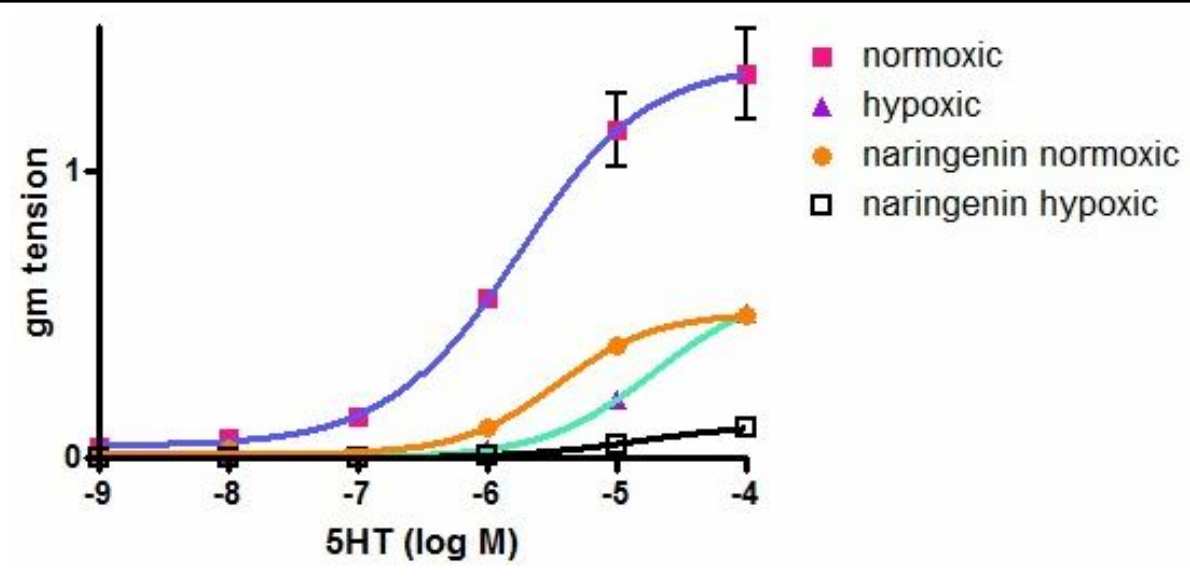

Figure 3C: $5 \mathrm{HT}(1 \mathrm{nM}-100 \mu \mathrm{M})$ induced concentration related con-tractile response in absence $\left(\mathrm{E}_{\max }\right)$ or in presence $\left(\mathrm{E}_{\mathrm{Bmax}}\right)$ of naringenin in normoxic and hypoxic pulmonary arterial rings of $C$. hircus.

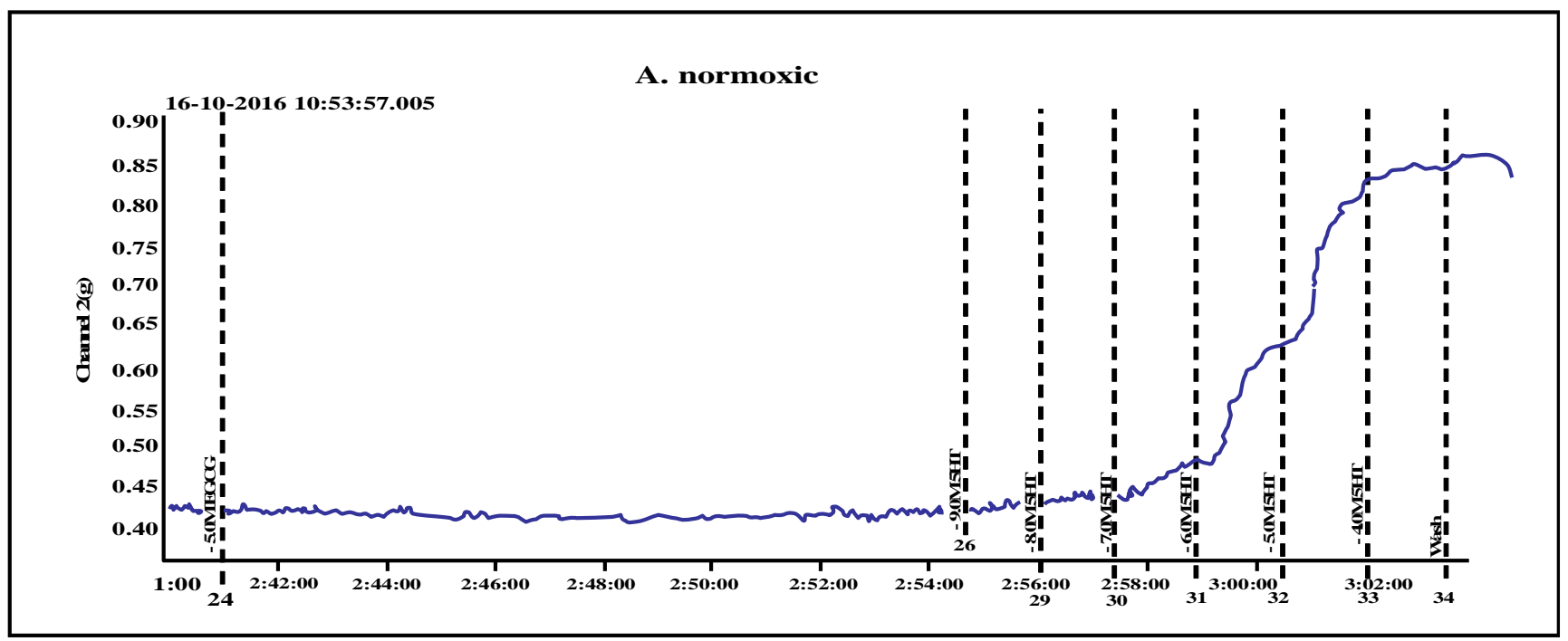




\section{B. hypoxic}

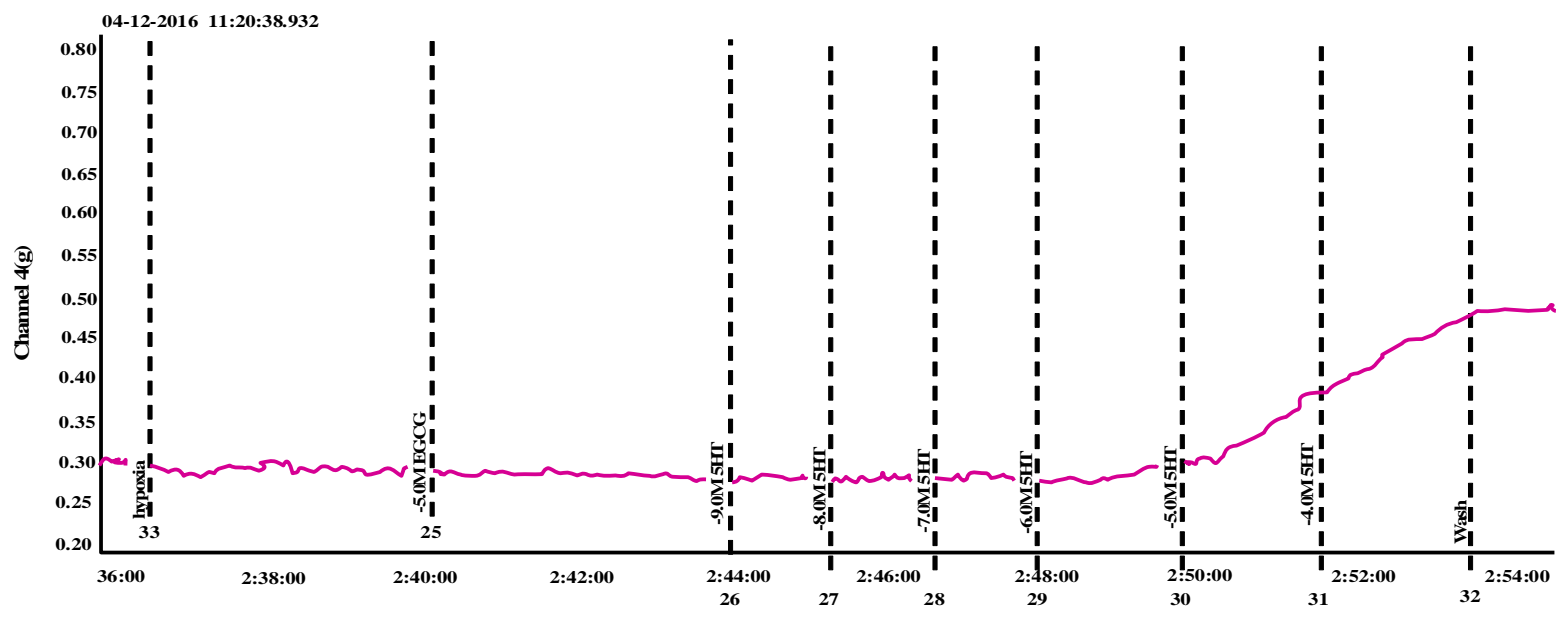

Figure 4:Representative raw trace showing effect of $5 \mathrm{HT}(1 \mathrm{nM}-100 \mu \mathrm{M})$ induced concentration related contractile response in presence of EGCG $(10 \mu \mathrm{M})$ in normoxic and hypoxic rings.

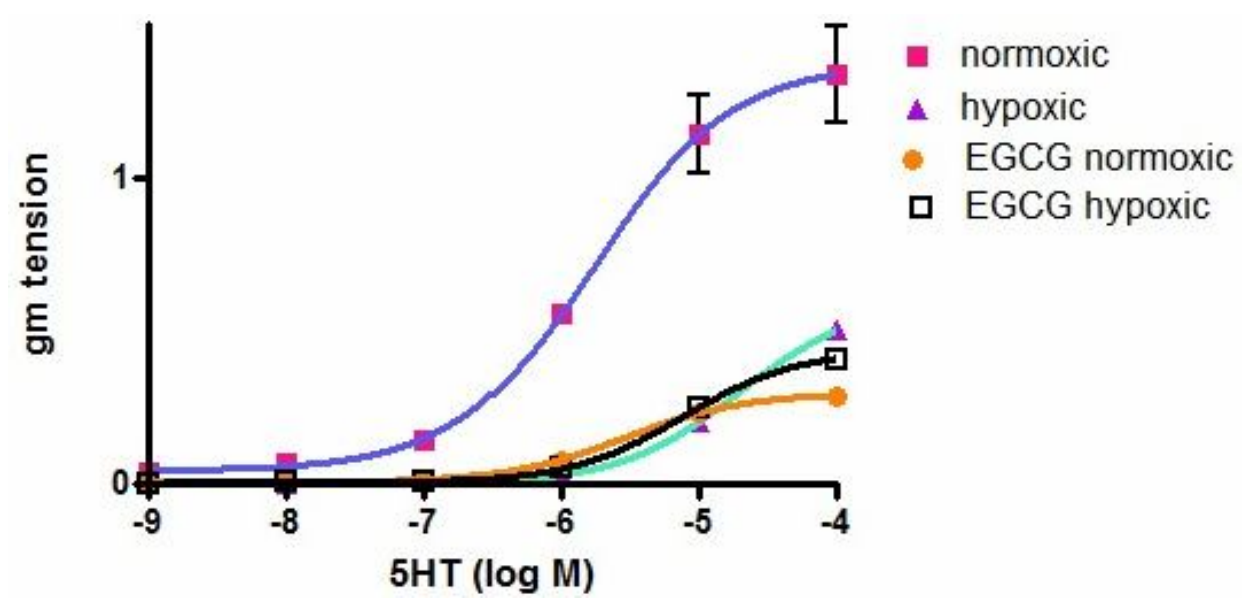

Figure 4C: $5 \mathrm{HT}(1 \mathrm{nM}-100 \mu \mathrm{M})$ induced concentration related contractile response in absence $\left(\mathrm{E}_{\max }\right)$ or in presence $\left(\mathrm{E}_{\mathrm{Bmax}}\right)$ of EGCG in normoxic and hypoxic pulmonary arterial rings of $C$. hircus.

A. normoxic

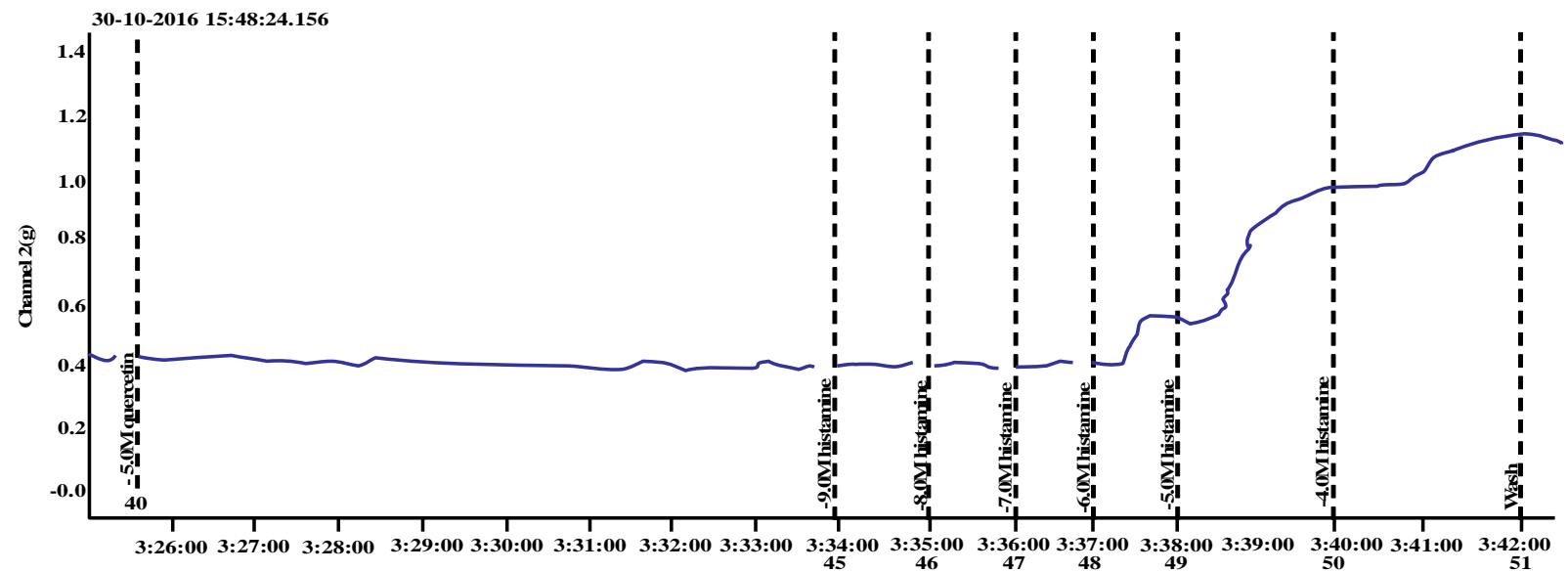




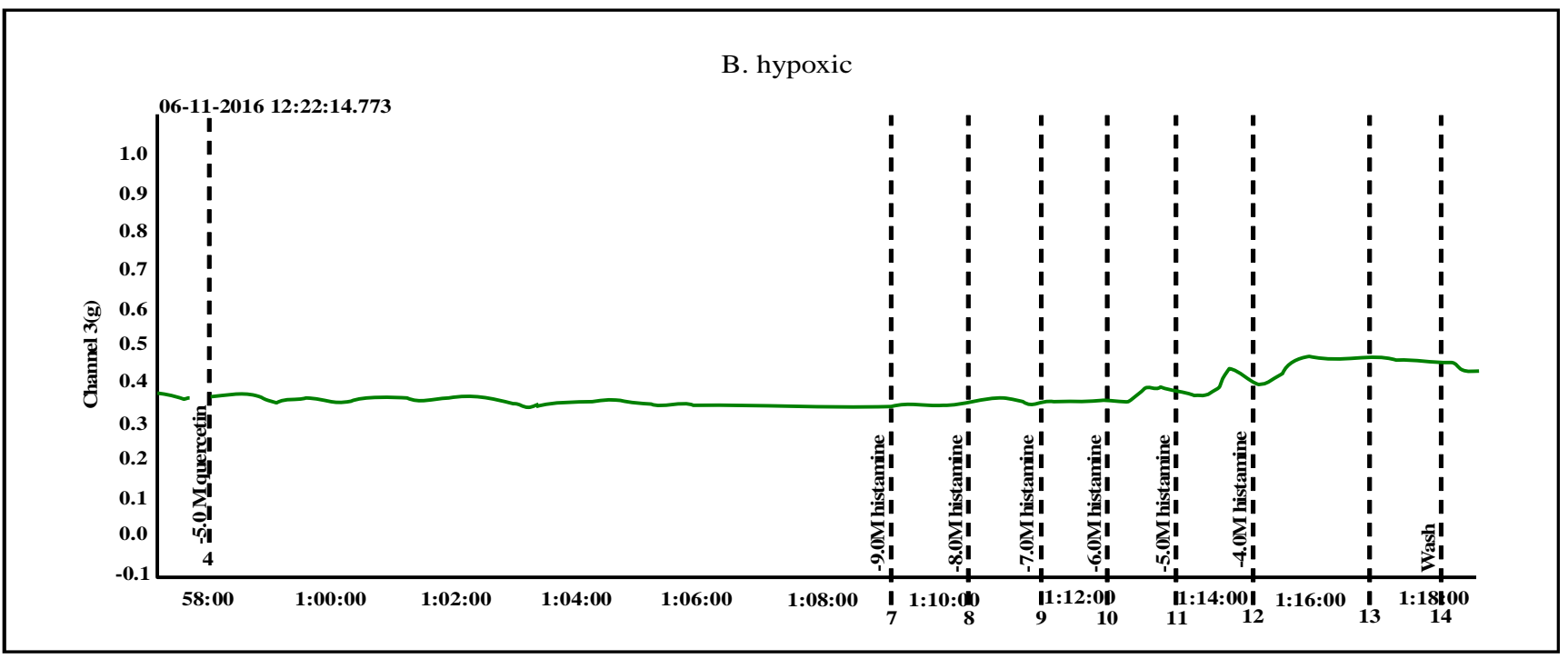

Figure 5: Representative raw trace showing effect of histamine $(1 \mathrm{nM}-100 \mu \mathrm{M})$ induced concentration related contractile response in presence of quercetin $(10 \mu \mathrm{M})$ in normoxic and hypoxic rings.

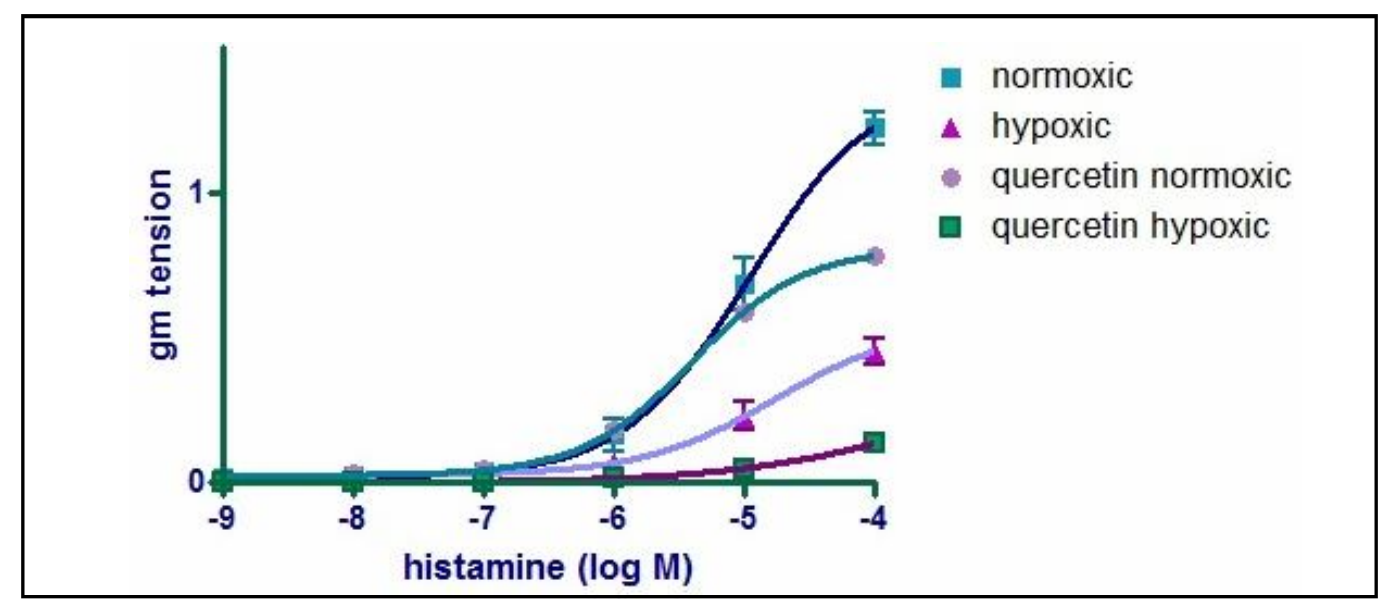

Figure 5C: Histamine $(1 \mathrm{nM}-100 \mu \mathrm{M})$ induced concentration related contractile response in absence $\left(\mathrm{E}_{\max }\right)$ or in presence $\left(\mathrm{E}_{\mathrm{B} \max }\right)$ of quercetin in Normoxic and Hypoxic pulmonary arterial rings of C. hircus.

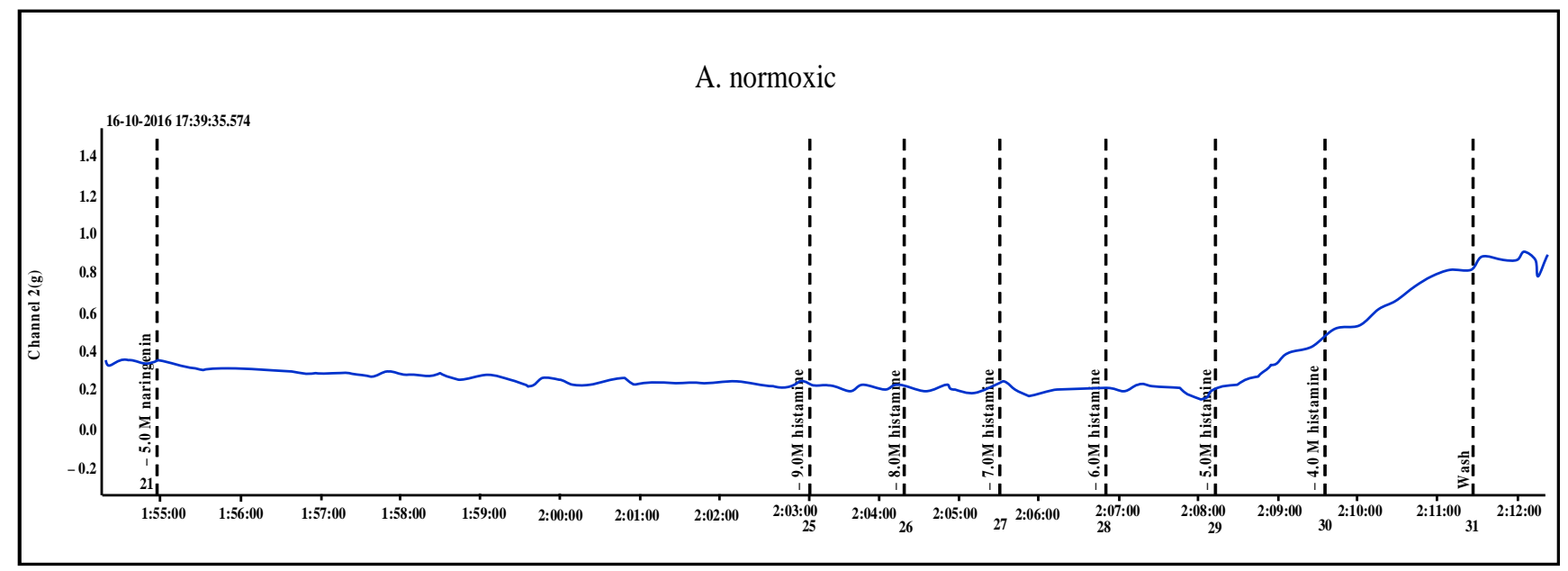


B. hypoxic

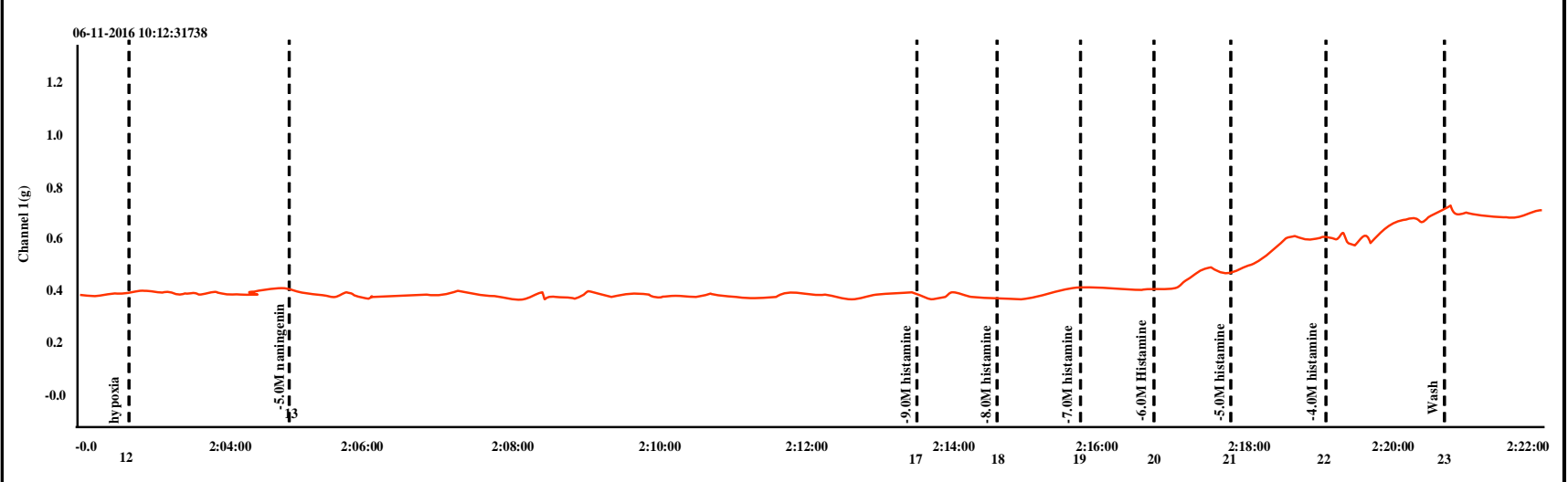

Figure 6: Representative raw trace showing effect of histamine $(1 \mathrm{nM}-100 \mu \mathrm{M})$ induced concentration related contractile response in presence of naringenin $(10 \mu \mathrm{M})$ in normoxic and hypoxic rings.

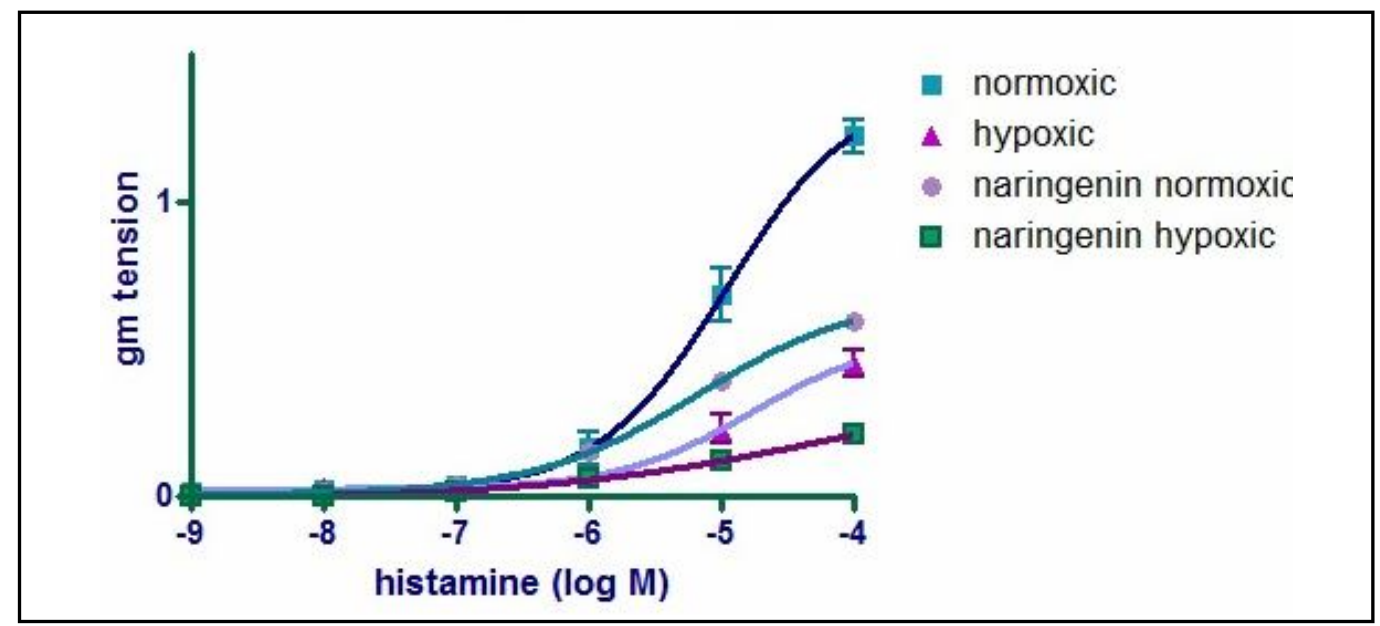

Figure 6C: Histamine $(1 \mathrm{nM}-100 \mu \mathrm{M})$ induced concentration related contractile response in absence $\left(\mathrm{E}_{\max }\right)$ or in presence $\left(\mathrm{E}_{\mathrm{Bmax}}\right)$ of naringenin in normoxic and hypoxic pulmonary arterial rings of $C$. hircus.

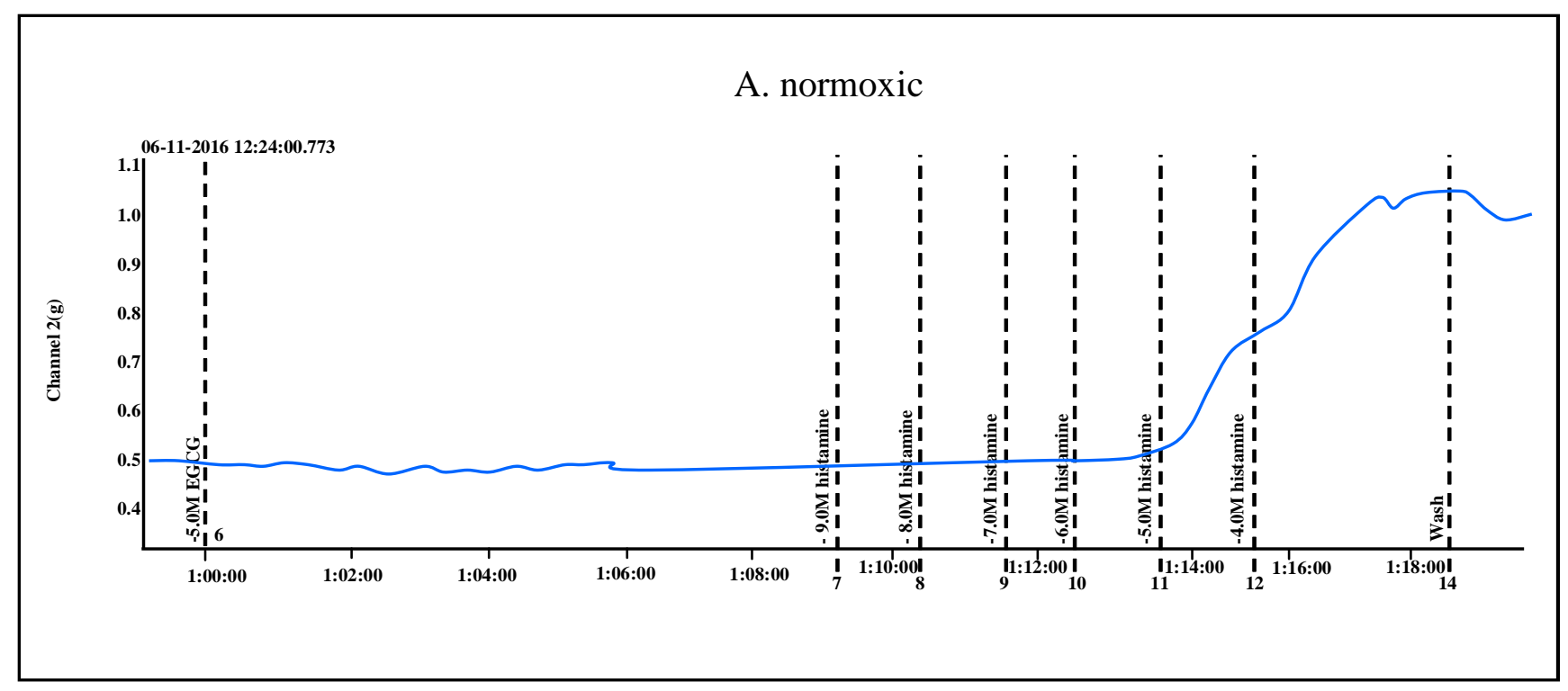




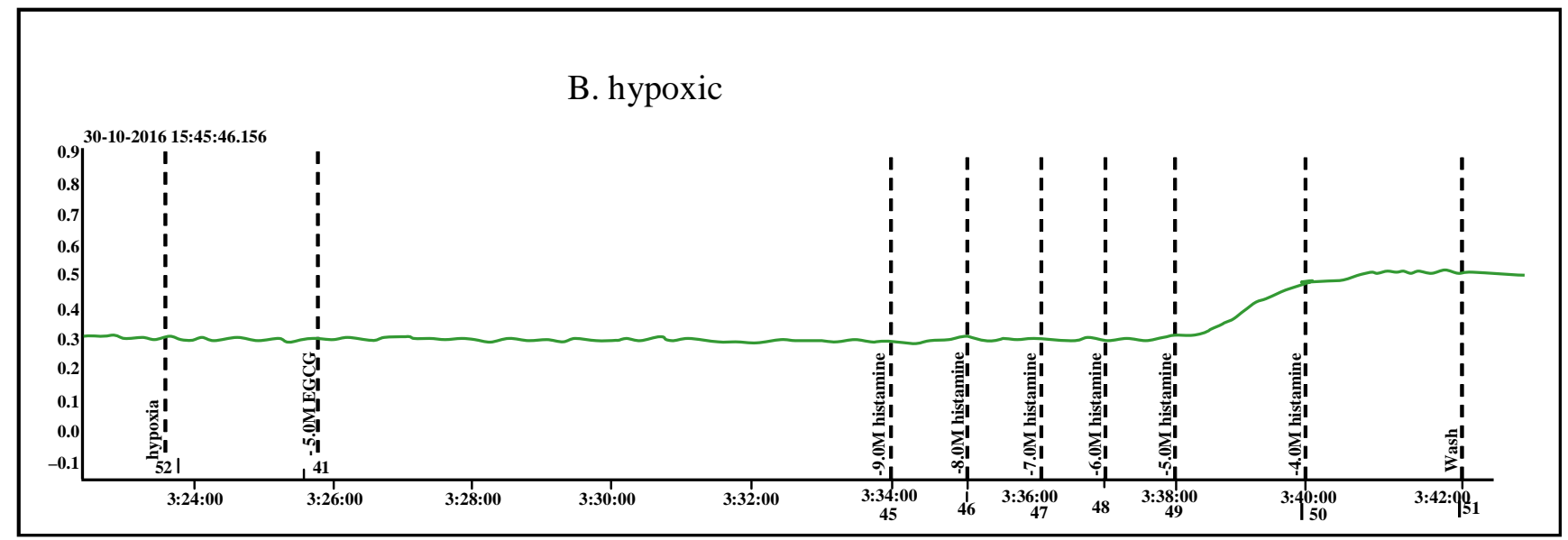

Figure 7: Representative raw trace showing effect of histamine $(1 \mathrm{nM}-100 \mu \mathrm{M})$ induced concentration related contractile response in presence of EGCG $(10 \mu \mathrm{M})$ in normoxic and hypoxic rings

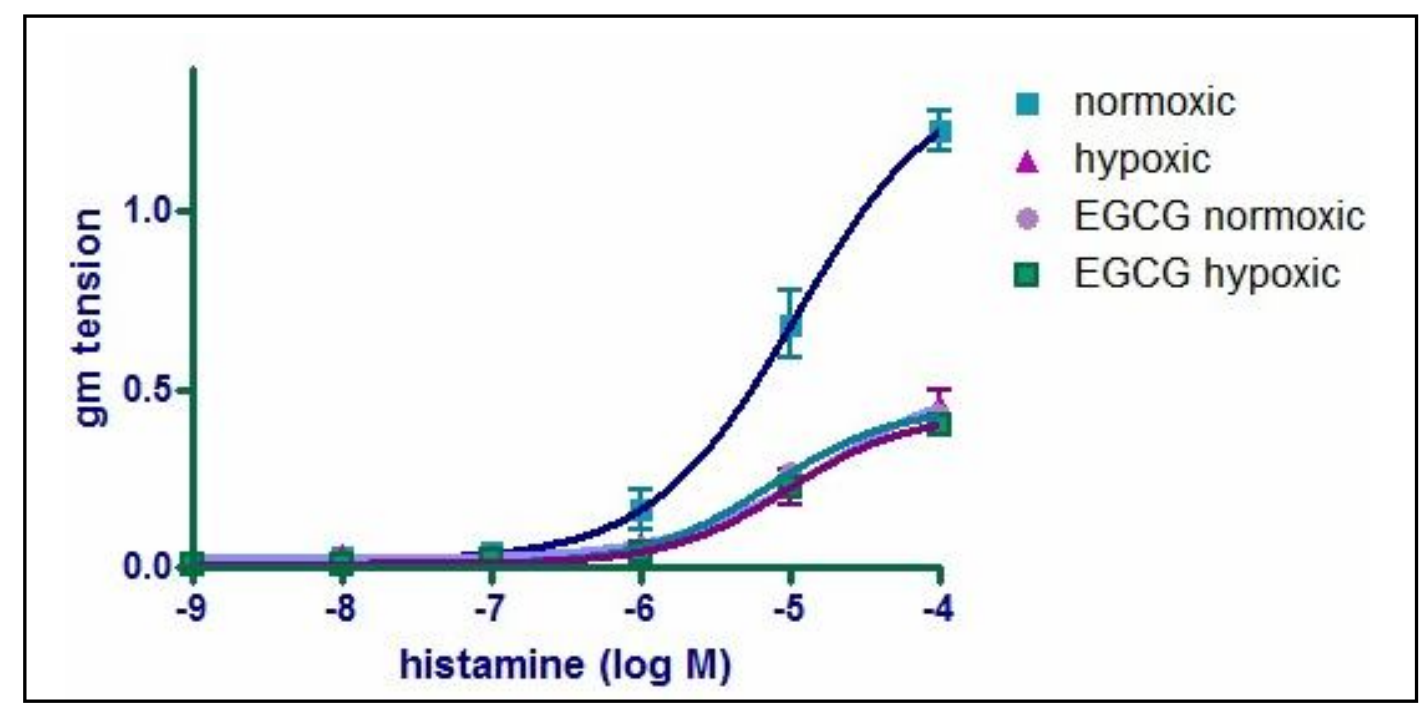

Figure 7C: Histamine $(1 \mathrm{nM}-100 \mu \mathrm{M})$ induced concentration related contractile response in absence $\left(\mathrm{E}_{\max }\right)$ or in presence $\left(\mathrm{E}_{\mathrm{Bmax}}\right)$ of $\mathrm{EGCG}$ in normoxic and hypoxic pulmonary arterial rings of $C$. hircus.

Effect of quercetin $(10 \mu \mathrm{M})$, naringenin $(10 \mu \mathrm{M})$ and EGCG $(10 \mu \mathrm{M})$ on histamine $(1 \mathrm{nM}-100 \mu \mathrm{M})$ concentration related contractile response elicited in normoxic and hypoxic pulmonary arterial rings.

Histamine-induced CRC response curve elicited in presence of quercetin $(10 \mu \mathrm{M})$ was shifted to right with significant $(p<0.001)$ increase in $\mathrm{EC}_{50}(5.40 \pm 0.004 \mu \mathrm{M})$ and with significant $(p<0.001)$ decrease in $\mathrm{E}_{\mathrm{Bmax}}(0.78 \pm 0.02 \mathrm{gms}, \mathrm{n}=6)$ in normoxic condition as compared to nontreated normoxic control $\left(\mathrm{EC}_{50} 5.01 \pm 0.01 \mu \mathrm{M}\right.$, $\mathrm{E}_{\max } 1.22 \pm 0.06 \mathrm{~g} ; \mathrm{n}=6$ ). Similarly, histamine induced CRC response curve elicited in presence of quercetin was shifted to right with significant $(p<0.001)$ decrease in $\left(\mathrm{EC}_{50} 4.62 \pm 0.02 \mu \mathrm{M}, \mathrm{E}_{\max } 0.14\right.$ $\pm 0.01 \mathrm{~g}, \mathrm{n}=6)$ in hypoxic rings in comparison with that of $\mathrm{EC}_{50}$ and $\mathrm{E}_{\mathrm{Bmax}}$ normoxic group (Figures 5A, B, C).
In presence of naringenin $(10 \mu \mathrm{M})$, histamine induced CRC response curve was shifted to right with significant $(p<0.001)$ increase in $\mathrm{EC}_{50}(5.29 \pm 0.03 \mu \mathrm{M})$ and with significant $(p<0.001)$ decrease in $\mathrm{E}_{\mathrm{Bmax}}(0.60 \pm 0.05 \mathrm{~g}, \mathrm{n}=6)$, in normoxic condition as compared to non-treated normoxic control $\left(\mathrm{EC}_{50} 5.01 \pm 0.01 \mu \mathrm{M}, \mathrm{E}_{\max } 1.22 \pm\right.$ $0.06 \mathrm{~g} ; \mathrm{n}=6$ ). Similarly, histamine induced CRC response curve elicited in presence of naringenin was shifted to right with significant $(p<0.05)$ decrease in $\left(\mathrm{EC}_{50} 5.13 \pm 0.06 \mu \mathrm{M}\right)$ with significant $(p<$ $0.001)$ decrease in $\left(\mathrm{E}_{\max } 0.21 \pm 0.004 \mathrm{~g}, \mathrm{n}=6\right)$ in hypoxic rings in comparison with that of $\mathrm{EC}_{50}$ and $\mathrm{E}_{\mathrm{Bmax}}$ normoxic group (Figures $6 \mathrm{~A}, \mathrm{~B}, \mathrm{C})$. 
CRC response curve induced by histamine in presence of EGCG (10 $\mu \mathrm{M})$ was shifted to right with significant $(p<0.001)$ increase in $\mathrm{EC}_{50}(5.35 \pm 0.04 \mu \mathrm{M})$ and with significant $(p<0.001)$ decrease in $\mathrm{E}_{\mathrm{Bmax}}(0.49 \pm 0.04 \mathrm{~g}, \mathrm{n}=6)$ in normoxic condition as compared to nontreated normoxic control $\left(\mathrm{EC}_{50} 5.01 \pm 0.01 \mu \mathrm{M}, \mathrm{E}_{\max } 1.22 \pm 0.06\right.$ $\mathrm{g} ; \mathrm{n}=6$ ). Similarly, histamine induced CRC response curve elicited in presence of EGCG was shifted to right with significant ( $p<$ $0.001)$ decrease in $\left(\mathrm{EC}_{50} 4.99 \pm 0.01 \mu \mathrm{M}, \mathrm{E}_{\max } 0.20 \pm 0.01 \mathrm{~g}\right)$ in hypoxic rings in comparison with that of $\mathrm{EC}_{50}$ and $\mathrm{E}_{\mathrm{Bmax}}$ of normoxic group (Figures 7A, B, C).

\section{Discussion}

The major observations are: (i) contractile response to 5-HT is greater than that of histamine, suggesting that this artery is more sensitive to serotonergic than histaminergic receptor. This further demonstrated that PA of $C h$ could be a good vascular model for evaluation of drugs acting on pulmonary artery, (ii) 5HT and histamine-induced vasotonic response were reduced by about $60 \%$ with experimental induction of acute hypoxia, (iii) a greater vasorelaxation effect was observed in 5HT-precontracted normoxic and hypoxic rings with naringenin, in histamine-precontracted in normoxic ring with EGCG and in histamine-precontracted hypoxic ring with quercetin indicating that all three polyphenols have potentials to control increased pulmonary vascular resistance in normoxic and hypoxic conditions.

In order to explain the effect of different polyphenols (quercetin, naringenin, EGCG) on vasotonic responses, 5HT concentration related contractile response was elicited either in absence or presence of quercetin or naringenin or EGCG in normoxic and hypoxic PA of $C h$. In the present study, it was observed that quercetin reduced the $5 \mathrm{HT}$ induced maximal response by $44 \%$ without altering the affinity suggesting that quercetin caused inhibition of 5HT-induced vasotonic effect, either by modulating 5HT receptor mediated signalling mechanism as in cultured coronary arteries (Deng et al. 2014); in pulmonary artery smooth muscle cells (Liu et al., 2007) or activating vasorelaxation mechanism of endothelial /nonendothelial cells as in bovine aortic endothelial cell cultures (Mcduffie et al., 1999) or interfering the $\mathrm{Ca}^{+2}$ entry pathways in arterial tissues like in isolated cerebral and peripheral arteries from rats (Chang and Owman 1987) ; in dog saphenous vein (Sumner et al., 1992); in bovine pulmonary arteries (Alapati et al., 2007).

In presence of quercetin, 5HT-induced contractile response in hypoxic pulmonary arterial rings of $C$. hircus was further attenuated with decrease in affinity by $2.31 \mathrm{log}$ unit and maximal response by $85 \%$. Our observation, demonstrated that quercetin inhibited the $5 \mathrm{HT}$ receptor-mediated contractile response almost identical in normoxic and hypoxic pulmonary arterial rings. This may be due to significantly restoration or up-regulation of $5-\mathrm{HT}_{2 \mathrm{~A}}$ receptors and reduced the Akt and S6 phosphorylation by quercetin (MoralesCano et al., 2014). Quercetin could be useful in the treatment of hypoxia of PAH as treatment with quercetin alone substantially ameliorated hypoxia induced brain dysfunctions and acts like a neuroprotectant (Sarkar et al., 2012).

Naringenin caused a clear cut rightward shift of 5HT-contractile response curve with decrease in affinity by 0.32 and maximal contraction by $63 \%$ in normoxic pulmonary arterial rings. This observation demonstrated that naringenin inhibited the vasotonic response of 5HT with significant attenuation of affinity and maximal contractile responses. Such effect could be due to either interference of agonist-receptor interaction or inhibition signalling pathways of $5 \mathrm{HT}$ receptor activation in mediating contractile response or activating vasorelaxation pathways via modulation of $\mathrm{NO} / \mathrm{PGI}_{2} / \mathrm{K}_{\mathrm{ATP}}$ channel/ $\mathrm{Na}^{+}$pump/ $\mathrm{Ca}^{+2}$ inactivation pathways as in the isolated mouse middle cerebral artery (Ni, 2004); in human, monkey and dog coronary artery (Toda, 1991). In hypoxic pulmonary arterial rings, naringenin inhibited the 5HT induced contraction with decrease in the affinity by about $1 \log$ unit and maximal response by $93 \%$. So, hypoxia further poteintiates the inhibitory effect of naringenin contractile response of 5HT in PA of $C h$. This reduced vasoconstriction to 5HT observed in hypoxic PA of $\mathrm{Ch}$ may be attributed to the decreased HIF- $1 \alpha$ and VEGF expression as in a murine model of hypobaric hypoxia (Sarkar et al., 2012) and may be mediated through serotongenic pathway (Dutt-Roy et al., 2015). The further inhibition of 5HT vasotonic response by naringenin could be mediated by modulation of signalling cascade or activation of vasorelaxation pathways which makes it suitable to be used as a drug in PAH combating hypoxia.

EGCG inhibited the 5HT induced contractile response with decease in affinity by $1.11 \log$ unit and $\mathrm{E}_{\mathrm{Bmax}}$ by $38 \%$ in normoxic and affinity by $0.66 \log$ unit and maximum response by $69 \%$ in hypoxic PA of $C h$. EGCG retains ability to reverse partially the affinity of 5 HT receptor as modulated by hypoxia. It does not further poteintiate the inhibitory effects on $5 \mathrm{HT}$ contraction as in case of quercetin and naringenin, implying that EGCG possesses possible vasoprotective potential as EGCG preserves endothelial functions by reducing the endogenous nitric oxide synthase inhibitor level (Tang et al., 2006) and can extend help as a protective measure for $\mathrm{PAH}$ against hypoxia.

Concisely, the percentage of inhibition of serotonergic receptorinduced vasototonic response mediated by quercetin, naringenin and EGCG is greater in hypoxic than normoxic tissues. Our observations clearly demonstrated that polyphenols exhibited significant inhibitory effect on 5HT induced vasotonic response in pulmonary arterial rings of $C$. hircus in the increasing order of vasorelaxation potency, i.e., naringenin > quercetin > EGCG in normoxic and hypoxic condition.

Histamine induced a concentration related contractile response in both normoxic and hypoxic pulmonary arterial rings of $C$. hircus. Concentration related curve of histamine was significantly shifted to right, decreased on affinity by 0.16 in hypoxic rings. As observed with 5HT, there was an identical inhibition of histamine contraction in pulmonary arterial rings of $C$. hircus under hypoxic condition. It could be predicted that hypoxia caused a downregulation and/or reduced function of histamine receptor that resulted in attenuation of function or expression of signalling molecules participated in histamine receptor coupling pathways as $\mathrm{H}_{2}$ receptor is coupled to both adenylyl cyclase and phospholipase $\mathrm{C}$ through $\mathrm{G}_{\mathrm{s}}$ and $\mathrm{G}_{\mathrm{q}}$ proteins respectively (Delvalle and Gantz, 1997; Hill et al.,1997; Leurs et al., 1994) and then histamine initiates two pathways which result in either an increased intracellular cyclic AMP or $\mathrm{Ca}^{2+}$ 
level (Fukushima et al., 1996; Kuhn et al.,1996; Wang et al., 1996) and histamine receptor activation leads to receptor desensitization (Smit et al., 1994).

Quercetin caused an inhibition of vasoconstriction of histamine reducing $\mathrm{EC}_{50}$ by $-0.39 \log$ unit and maximum relaxation by $36 \%$ in nomoxic rings. The maximal contractile response of histamine was augmented to $89 \%$ in hypoxic rings with $0.23 \mathrm{log}$ unit reduction in affinity. This result demonstrated that quercetin exhibited a greater inhibitory effect in histamine mediated vasotonic response in hypoxic PA of $\mathrm{Ch}$ than normoxic ones as quercetin increases NO bioavailability in endothelial cells, plays a role in the vascular protective effects associated with improved endothelial cell function by inducing vasorelaxation through an eNOS phosphorylation process blocked by an increase in catalase activity, $\mathrm{Ca}^{2+}$ mediated eNOS dependent and independent pathways (Khoo et al., 2010) by which quercetin reduces inflammation and cerebral edema associated with altitude diseases without the side effects of steroid therapy (Patir et al. 2012) and is used as antioxidants used in the altitude sickness (Sarkar et al., 2012) in rats and thus paves way to be used against hypoxia in $\mathrm{PAH}$.

Naringenin inhibited histamine induced contractile response with $51 \%$ and $83 \%$ attenuation of maximal contractile response with increase in affinity of histamine receptor in normoxic and hypoxic pulmonary arterial rings of $C$. hircus, respectively. This may be due to the mechanism involving the inhibition of formation and release of endogenous histamine in the gastric mucosa of rats is implicated in the protective effect of naringenin (Parmar, 1984). Also, grapefruit juice increases the bioavailability of $\mathrm{H}_{1}$ antihistamines through their interaction in the intestines (Bartra, et al., 2006) as inhibits CYP3A4 by the active metabolite naringenin (Criado et al., 2010) and strongly inhibits histamine release from rat mast cells to suppress allergic reaction through the inhibition of histamine release and is known as a histidine decarboxylase inhibitor (Yamamoto et al., 2014) which can also thus help to ameliorate PAH combating hypoxia.

ECCG also inhibited the histamine contraction with $60 \%$ and $84 \%$ attenuation of maximal contractile response with increase in affinity of histamine receptor in normoxic and hypoxic PA of $C h$, respectively. This finding clearly demonstrates that vasocontration to histamine in PA of $\mathrm{Ch}$ is reduced in both normoxic and hypoxic conditions as the bioactive compound epigallocatechin-3-gallate (EGCG) targets histamine-producing cells producing great alterations in their behavior, proliferative potential, adhesion, migration, invasion potentials, as a potent inhibitor of the histamine-producing enzyme, histidine decarboxylase thus extends potent anti-inflammatory, antitumoral, and antiangiogenic effects (Melgarejo et al., 2010) and can be helpful in improving blood circulation of hypoxic blood vessels in $\mathrm{PAH}$.

The vasorelaxation of quercetin, naringenin and EGCG in histamineprecontracted rings is more in hypoxic than normoxic rings. Our observations clearly demonstrated that polyphenols exhibited significant inhibitory effects on histamine induced vasotonic response in pulmonary arterial rings of $C$. hircus in the order of potency, i.e., EGCG> naringenin >quercetin in normoxic and quercetin $>$ EGCG > naringenin in hypoxic condition.

\section{Conclusion}

PA of $C h$ can be used as a vascular prototype model to evaluate the mechanisms of vasoreactivity of different drugs and nutraceuticals in addition to the rodent model. While comparing the vasotonic responses of 5HT and histamine in PA of $C h$, the PA of $C h$ shows more sensitivity to $5 \mathrm{HT}$ than histamine which indicates that there is a greater function and expression of 5HT receptor than histamine receptor. Hypoxia reduced the 5HT and histamine-induced contractile response by $60 \%$ that could be probably due to reduced function and expression or downregulation of these receptors. Polyphenols like quercetin, naringenin and EGCG exhibited vasorelaxation in both 5HT and histamine receptor activated contraction in both normoxic and hypoxic conditions. It is interesting to note that it could cause vasorelaxation where the vascular resistance is severely decreased. Hence, the use of these polyphenols could be effective in protecting the normal vasoreactivity during inflammatory damage of PA. In hypoxic PA where the vasotonic response is greatly diminished, these polyphenols could be used to improve blood circulation in the lungs.

\section{Acknowledgments}

The authors are thankful to Dean, College of Veterinary Science and Animal Husbandry, Orissa University of Agriculture and Technology for providing funds and necessary facilities to conduct the research work.

\section{Conflict of interest}

We declare that we have no conflict of interest.

\section{References}

Abaza, M.S.; Orabi, K.Y.; Al-Quattan, E. and Al-Attiyah, R.J. (2015). Growth inhibitory and chemo-sensitization effects of naringenin, anatural flavanone purified from Thymus vulgaris, on human breast and colorectal cancer. Cancer Cell International, 15:46.

Aggio, A.; Grassi, D. and Onori, E. (2013). Endothelium/nitric oxide mechanism mediates vasorelaxation and counteracts vasoconstriction induced by low concentration of flavanols. European Journal of Nutrition, 52:263-272.

Ajay, M.; Gilani, A.U. and Mustafa, M.R. (2003). Effects of flavonoids on vascular smooth muscle of the isolated rat thoracic aorta. Life Sci., 74:603-612.

Alapati ,V.R.; McKenzie, C.; Blair, A.; Kenny, D.; MacDonald, A. and Shaw, A.M. (2007). Mechanisms of U46619- and 5-HT-induced contraction of bovine pulmonary arteries: role of chloride ions. British Journal of Pharmacology.,151(8).:1224-1234.

Alvarez, E.; Campos-Toimil, M. and Justiniano-Basaran, H. (2006). Study of the mechanisms involved in the vaso-relaxation induced by (-).epigallocatechin-3-gallate in rat aorta. British Journal of Pharmacology, 147:269-280.

Amira, S.; Rotondo, A. and Mule, F. (2008). Relaxant effects of flavonoids on the mouse isolated stomach: Structure-activity relationships, Pulmonary, Gastrointestinal and Urogenital Pharmacology. European Journal of Pharmacology, 599(1-3):126-130 .

Auger, C.; Kim, J.H. and Chabert, P. (2010). The EGCG-induced redoxsensitive activation of endothelial nitric oxide synthase and relaxation are critically dependent on hydroxyl moieties. Biochemical and Biophysical Research Communications, 393:162-167.

Bartra, J.; Velero, A.L.; delCurvillo, A.; Davila, I.; Jauregui, I. and Montoro J. (2006). Interactions of the $\mathrm{H} 1$ antihistamines. Journal of Investigational Allergology and Clinical Immunology,16(1):29-36. 
Boucherat, O.; Chabot, S.; Antigny, F and Perros, F.; Provencher, S. and Bonnet, S. (2015). Potassium channels in pulmonary arterial hypertension. European Respiratory Journal,46: 1167-1177.

Chan, E.C.; Pannangpetch, P. and Woodman, O.L. (2000). Relaxation to flavones and flavonols in rat isolated thoracic aorta: mechanism of action and structure-activity relationships. J . Cardiovasc. Pharmacol., 35:326-333.

Chang, J.Y. and Owman C. (1987). Involvement of specific receptors and calcium mechanisms in serotonergic contractile response of isolated cerebral and peripheral arteries from rats. J. Pharmacol. Exp. Ther., 242(2).:629-636.

Chen, C.K. and Pace-Asciak C.R. (1996). Vasorelaxing activity of resveratrol and quercetin in isolated rat aorta. Gen. Pharmacol., 27:363-366.

Chen, Z.; Yongzhou, H.; Haohao, W.; and Huidi, J. (2004). Synthesis and biological evaluation of flavonoids as vasorelaxant agents. Bioorganic \& medicinal chemistry letters, 14(15).: 39493952 .

Criado, P.R.; Criado, R.F.J.; Maruta, C.W. and Machado, F.C.A. (2010). Histamine, histamine receptors and antihistamines: new concepts. The Brazilian Annals of Dermatology, 85(2).: 195-210.

Delvalle J. and Gantz I. (1997). Novel insights into histamine $\mathrm{H}_{2}$ receptor biology. Am. J. Physiol., 36:G987-G996.

Deng, C.Y.; Yang, H.; Kuang, S.J.; Rao, F.; Xue, Y.M.; Zhou, Z.L., et al. (2014) Upregulation of 5-Hydroxytryptamine Receptor Signaling in Coronary Arteries after Organ Culture. PLoS ONE, 9(9).: e107128.

Duarte, J.; Jimenez, R.; Villar, I.C.; Perez-Vizcaino, F.; Jimenez, J. and Tamargo, J. (2001). Vasorelaxant effects of the bioflavonoid chrysin in isolated rat aorta. Planta. Medica., 67: 567-569

Duarte, J.; Perez-Vizcaino, F.; Zarzuelo, A.; Jimenez, J.and Tamargo J. (1993) Vasodilator effects of quercetin in isolated rat vascular smooth muscle. Eur. J. Pharmacol., 239:1-7.

Dutt-Roy, R.; Kayalvizhi, E.; Manikandan, B.; Lakshmi, D. and Chandrasekhar, M. (2015). The Possible Pathways of Anti-Depressant Activity of Naringenin in Albino Mice Using Forced Swim Test Model of Depression. International Journal of Pharmacology and Biological Sciences, 6(4): : $119-127$.

Fallahi, F.; Roghani, M. and Moghadami, S. (2012). Citrus flavonoid naringenin improves aortic reactivity in streptozotocin-diabetic rats. Indian Journal of Pharmacology, 44:382-386.

Ferrali, M.C.; Signorini, B.; Caciotti, L.; Sugherini, L.; Ciccoli, D.G. and Comporti, M. (1997). Protection against oxidative damage of erythrocyte membrane by the flavonoid quercetin and its relation to iron chelating activity. FEBS letters, 416(2).: 123-129.

Fukushima, Y.; Asano, T.; Katagiri, H.; Aihara, M.; Saitoh, T.; Anai, M.; Funaki, M.; Ogihara,T.; Inukai, K.; Matsuhashi, N.; Oka, Y.; Yazaki, Y. and Sugano, K. (1996). Interaction between the two signal transduction systems of the histamine $\mathrm{H}_{2}$ receptor: Desensitizing and sensitizing effects of histamine stimulation on histamine-dependent cAMP production in Chinese hamster ovary cells. Biochem. J.,320:27-32

Fusi, F.; Saponara, S.; Pessina, F.; Gorelli, B. and Sgaragli, G. (2003). Effects of quercetin and rutin on vascular preparations: a comparison between mechanical and electrophysiological phenomena. Eur. J. Nutr.,42:10-17.

Guo, S.; Bezard, E. and Zhao, B. (2005). Protective effect of green tea polyphenols on the SH-SY5Y cells against 6-OHDA induced apoptosis through ROS-NO pathway. Free Radic Biol Med., 39(5).:682-95.

Harwood, M.; Danielewska-Nikiel, B.; Borzelleca, J.F.; Flamm, G.W.; Williams, G.M. and Lines, T.C. (2007). A critical review of the data related to the safety of quercetin and lack of evidence of in vivo toxicity, including lack of genotoxic/carcinogenic properties. Food and chemical toxicology, 45(11).: 2179-2205.
Hertog MG, Feskens EJ, Hollman PC, Katan MB and Kromhout D. (1993). Dietary antioxidant flavonoids and risk of coronary heart disease:the Zutphen elderly study. Lancet 342: 1007-1011.

Hill S.J.; Ganellin, C.R.; Timmerman, H.; Schwartz, J.C., Shankley, N.P.; Young, J.M.; Schunack, W.; Levi, R. and Haas, H.L. (1997). International union of pharmacology. XIII. Classification of histamine receptors. Pharmacol. Rev., 49:253-278.

Khoo, N.K.; White, C.R.; Pozzo-Miller, L.; Zhou, F.; Constance, C.; Inoue, T.; Patel, R.P. and Parks, D.A. (2010). Dietary flavonoid quercetin stimulates vasorelaxation in aortic vessels. Free Radical Biology \& Medicine, 49: $339-347$

Kim, H.J. and Kim, B.J. (2017). Naringenin inhibits pacemaking activity in interstitial cells of Cajal from murine small intestine. Integrative Medicine Research.,6(2).:149-155.

Kim, J.A.; Formoso, G. and Li, Y. (2007). Epigallocatechin gallate, a green tea polyphenol, mediates NO-dependent vasodilation using signaling pathways in vascular endothelium requiring reactive oxygen species and Fyn. The Journal of Biological Chemistry, 282:13736-13745.

Kuhn, B.; Schmid, A.; Harteneck, C.; Gudermann, T. and Schultz, G. (1996). G proteins of the $\mathrm{Gq}$ family couple the $\mathrm{H}_{2}$ histamine receptor to phospholipase. C. Mol. Endocrinol.,10:1697-1707.

Lambert, J.D. and Elias, R.J. (2010). The antioxidant and pro-oxidant activities of green tea polyphenols: A role in cancer prevention. Arch Biochem Biophys.; 501(1).:65-72.

Lee, S.; Lee, C.H.; Moon, S.S.; Kim, E.; Kim, C.T. and Kim, B.H (2003). Naringenin derivatives as anti-atherogenic agents. Bioorganic \& Medical Chemistry Letters,13:3901-3903.

Leurs, R.; Smit, M.J.; Menge, W.M.B.P. and Timmerman, H. (1994). Pharmacological characterization of the human histamine $\mathrm{H}_{2}$ receptor stably expressed in Chinese Hamster Ovary cells. Br. J. Pharmacol., 112:847-854

Liu, X.; Wang, N.; Fan, S.; Zheng, X.; Yang, Y. and Zhu, Y. (2016). The citrus flavonoid naringenin confers protection in a murine endotoxaemia model through AMPK-ATF3-dependentnegative regulation of the TLR4 signalling pathway. Science Reports, 6:39735.

Liu, Y.; Li, M.; Warburton, R.R.; Hill, N.S. and Fanburg, B.L.(2007). The 5-HT transporter transactivates the PDGFbeta receptor in pulmonary artery smooth muscle cells. FASEB J., 21(11).:2725-34.

Lorenz, M.; Klinkner, L.; Baumann, G.; Stangl, K. and Stangl, V. (2015). Endothelial NO Production Is Mandatory for Epigallocatechin-3Gallate induced Vasodilation: Results from eNOS Knockout (eNOS/ ). Mice. Journal of Cardiovascular Pharmacology, 65(6).: 607610

Lorenz, M.; Wessler, S.; Follmann, E.; Michaelis, W.; Dusterhoft ,T.; Baumann, G.; Stangl, K. and Stangl, V. (2004). A constituent of green tea, epigallocatechin- 3-gallate, activates endothelial nitric oxide synthase by a phosphatidylinositol- 3-OH-kinase-, cAMPdependent protein kinase-, and Aktdependent pathway and leads to endothelial-dependent vasorelaxation. Journal of Biological Chemistry, 279: 6190-6195.

Mariìn, C.; Boutaleb-Charki, S.; Diìaz, J.G.; Huertas, O.; Rosales, M.J.; PérezCordon, G.; Guitierrez-Sánchez, R. and Sánchez-Moreno, M. (2009). Antileishmaniasis activity of flavonoids from Consolida oliveriana. Journal of natural products, 72(6).: 1069-1074.

Mcduffie, J.E.; Coaxum, S.D. and Maleque, M.A. (1999). 5-Hydroxytryptamine Evokes Endothelial Nitric Oxide Synthase Activation in Bovine Aortic Endothelial Cell Cultures. Proceedings of The Society for Experimental Biology and Medicine 221(4).: 386-390.

Melgarejo, E.; Urdiales, J.L.; Sánchez-Jiménez, F. and Medina, M.Á. (2010). Targeting polyamines and biogenic amines by green tea epigallocatechin-3-gallate. Amino acids. 38(2).:519-523. 
Mershiba, S.D.; Dassprakash, M.V. and Saraswathy, S.D. (2013). Protective effect of naringenin on hepatic and renal dysfunction andoxidative stress in arsenic intoxicated rats. Molecular and Biological Reports, 40:3681-3691.

Morales-Cano, D.; Menendez, C.; Moreno, E.; Moral-Sanz, J.; Barreira, B. and Galindo, P. (2014). The Flavonoid Quercetin Reverses Pulmonary Hypertension in Rats. PLoS ONE, 9(12).: e114492.

Morel, I.; Gérard, L.; Cogrel, P.; Sergent, O.; Pasdeloup, N.; Brissot, P.; Cillard, P. and Cillard, J. (1993). Antioxidant and iron-chelating activities of the flavonoids catechin, quercetin and diosmetin on iron-loaded rat hepatocyte cultures. Biochemical pharmacology, 45(1):13-19.

Ni, B. (2004).. Pharmacology of the isolated mouse middle cerebral artery (T).. Retrieved from https://open.library.ubc.ca/cIRcle/ collections/831/items/1.009178

Nie, G.; Jin, C.; Cao, Y.; Shen, S. and Zhao, B. (2002). Distinct effects of tea catechins on 6-hydroxydopamine-induced apoptosis in PC12 cells. Arch Biochem Biophys., 397(1).:84-90.

Orallo, F.; Camina, M.; Alvarez, E.; Basaran, H. and Lugnier, C. (2005) Implication of cyclic nucleotide phosphodiesterase inhibition in the vasorelaxant activity of the citrus-fruits flavonoid (+/").naringenin. Planta. Med.,71:99-107.

Parmar NS. 1984. The Gastric Anti-Ulcer Activity of Naringenin, a specific histidine decarboxylase inhibitor. International Journal of Tissue Reactions.5: 415-420.

Patir, H.; Sarada, S.K.S.; Singh, S.; Mathew, T.; Singh, B. and Bansal, A. (2012). Quercetin as a prophylactic measure against high altitude cerebral edema. Free Radical Biology and Medicine, 53(4). , 659-668.

Perez-Vizcaino, F.; Ibarra, M.; Cogolludo, A.L.; Duarte, J.; Zaragoza-Arnaez, F.; Moreno, L.; et al. (2002).. Endothelium-independent vasodilator effects of the flavonoid quercetin and its methylated metabolites in rat conductance and resistance arteries. J. Pharmacol. Exp.Ther., 302:66-72.

Potenza, M.A.; Marasciulo, F.L.; Tarquinio, M.; Tiravanti, E.; Colantuono, G.; Federici, A.; Kim, J.; Quon, M.J. and Montagnani, M. (2007).. EGCG, a green tea polyphenol, improves endothelial function and insulin sensitivity, reduces blood pressure, and protects against myocardial I/R injury in SHR. American Journal of Physiology Endocrinology and Metabolism, 292: 1378-1387.

Rogerio, A.P.; Kanashiro, A.; Fontanari, C.; VG da Silva, E.; Lucisano-Valim Y.M.; Soares, E.G. and Faccioli, L.H. (2007).. Anti-inflammatory activity of quercetin and isoquercitrin in experimental murine allergic asthma. Inflammation Research, 56(10).: 402-408.

Sanders, K. M., Ward S.M. and Koh, S.D. (2014).. Interstitial cells: regulators of smooth muscle function. Physiological Revue, 94:859-907.

Saponara, S.; Testai, L.; Iozzi, D.; Martinotti, E.; Martelli, A.; Chericoni, S.; Sgaragli, G.; Fusi, F. and Calderone, V. (2006).. (+/-).-Naringenin as large conductance $\mathrm{Ca}^{2+}$-activated $\mathrm{K}^{+}\left(\mathrm{BK}_{\mathrm{Ca}}\right)$. channel opener in vascularsmooth muscle cells. British Journal of Pharmacology, 149:1013-1021.

Sarkar, A.; Angeline, M.S.; Anand, K,; Ambasta, R.K. and Kumar, P. (2012).. Naringenin and quercetin reverse the effect of hypobaric hypoxia and elicit neuroprotective response in the murine model. Brain Research, 24(1481).: 59-70.
Shi, Y.; Dai, J.; Liu, H.; Li, R.R.; Sun, P.L. and Du, Q. (2009).. Naringenin inhibits allergen-induced airway inflammation and airway responsiveness and inhibits NF-kappaB activity in a murine model of asthma. Canadian Journal of Physiology and Pharmacology,87:729-735.

Singh, R.; Akhtar, N. and Haqqi, T.M. (2010). Green tea polyphenol epigallocatechin-3-gallate: inflammation and arthritis. [corrected]. Life Sci. Elsevier Inc., 86(25-26).:907-18.

Sitbon, O.; Jaý, X.; Savale, L.; Cottin, V.; Bergot, E.; Macari, E.A.; Bouvaist, H.; Dauphin, C.; Picard, F.; Bulifon, S.; Montani, D.; Humbert, M. and Simonneau, G. (2014).. Upfront triple combination therapy in pulmonary arterial hypertension: a pilot study on Pulmonary Vascular Diseases. European Respiratory Journal, 43: 1691-1697.

Smit, M.J.; Leurs, R.; Shukrula, S.R.; Bast A. and Timmerman, H. (1994).. Rapid desensitization of the histamine $\mathrm{H}_{2}$ receptor on the human monocytic cell line U937. Eur. J. Pharmacol.;288:17-25.

Sumner, M.J.; Feniuk, W.; McCormick, J.D. and Humphrey, P.P. (1992).. Studies on the mechanism of 5-HT1 receptor-induced smooth muscle contraction in dog saphenous vein. Br. J. Pharmacol., 105(3).:6038 .

Tang, W.J; Hu, C.P.; Chen, M.F.; Deng, P.Y.; Li, Y.J. (2006).. Epigallocatechin gallate preserves endothelial function by reducing the endogenous nitric oxide synthase inhibitor level. Canadian Journal of Physiology and Pharmacology, 84:163-171.

Toda, N. (1991). Human, Monkey and Dog Coronary Artery Responses to Serotonin and 5-Carboxamidotryptamine. Serotonin: Molecular Biology, Receptors and Functional Effects , 275-281

Tsai, S.J.; Huang, C.S.; Mong, M.C.; Kam, W.Y.; Huang, H.Y. and Yin, M.C. (2012).. Anti-inflammatory and anti fibrotic effects of naringenin indiabetic mice. Journal of Agricultural Food Chemistry, 60:514-521.

Wang, L.; Gantz, I. and Del Valle J. (1996).. Histamine $\mathrm{H}_{2}$ receptor activates adenylate cyclase and PLC via separate GTP-dependent pathways. Am. J. Physiol.; 271:G613-G620.

Weinreb, O.; Mandel, S.; Amit, T. and Youdim M.B.H. (2004).. Neurological mechanisms of green tea polyphenols in Alzheimer's and Parkinson's diseases. J Nutr Biochem.,15(9).:506-16. doi: 10.1016/ j.jnutbio.2004.05.002.

Yamamoto, T.; Yoshimura, M.; Yamaguchi, F.; Kouchi, T.; Tsuji, R.; Saito, M.; Obata, A. and Kikuchi, M. (2014).. Anti allergic activity of naringenin chalone from a tomato skin extract. Bioscience Biotechnology Biochemistry, 68(8):: 1706-1711.

Yamamoto, Y. and Oue, E. (2006).. Antihypertensive effect of quercetin in rats fed with a high-fat high-sucrose diet. Biosci Biotechnol Biochem. 2006 Apr;70(4).:933-9.

Yang, Z.; Pan, A.; Zuo, W.; Guo, J. and Zhou, W. (2014).. Relaxant effect of flavonoid naringenin on contractile activity of rat colonic smooth muscle. Journal of Ethnopharmacology, 155:1177-83.

Yang, Z.H.; Pan, A.; Zuo, W.L.; Guo, J.H. and Zhou W.L. (2014). Relaxant effect of flavonoid aringenin on contractile activity of rat colonic smooth muscle. Journal of Ethnopharmacology, 155 (2).:1177-1183. 